\title{
Local Mesenchymal Stem/Progenitor Cells Are a Preferential Target for Initiation of Adult Soft Tissue Sarcomas Associated with p53 and Rb Deficiency
}

Jinhyang Choi, Stephen J. Curtis, David M. Roy, Andrea Flesken-Nikitin, and Alexander Yu. Nikitin

From the Department of Biomedical Sciences, Cornell University, Ithaca, New York

The cell of origin and pathogenesis of the majority of adult soft tissue sarcomas (STS) remains poorly understood. Because mutations in both the $P 53$ and $R B$ tumor suppressor genes are frequent in STS in humans, we inactivated these genes by Cre-loxP-mediated recombination in mice with floxed $p 53$ and $R b$. Ninety-three percent of mice developed spindle cell/ pleomorphic sarcomas after a single subcutaneous injection of adenovirus carrying Cre-recombinase. Similar to human STS, these sarcomas overexpress Cxcr4, which contributes to their invasive properties. Using irradiation chimeras generated by transplanting bone marrow cells from mice carrying either the Rosa26Stop ${ }^{\text {loxP }}$ LacZ or the $Z / E G$ reporter, as well as the floxed $p 53$ and $R b$ genes, into irradiated $P 53^{\text {loxP/loxP }} \mathrm{Rb}^{\text {loxp/loxP }}$ mice, it was determined that sarcomas do not originate from bone marrow-derived cells, such as macrophages, but arise from the local resident cells. At the same time, dermal mesenchymal stem cells isolated by strict plastic adherence and low levels of Sca-1 expression (Sca- $1^{\text {low }}$, $\mathrm{CD} 1^{\text {neg }} \mathrm{CD} 45^{\text {neg }}$ ) have shown enhanced potential for malignant transformation according to soft agar, invasion, and tumorigenicity assays, after the conditional inactivation of both $p 53$ and $R b$. Sarcomas formed after transplantation of these cells have features typical for undifferentiated high-grade pleomorphic sarcomas. Taken together, our studies indicate that local Sca-1 ${ }^{\text {low }}$ dermal mesenchymal stem/progenitor cells are preferential targets for malignant transformation associated with deficiencies in both $p 53$ and $R \boldsymbol{B}$. (Am J Pathol 2010, 177:2645-2658; DOI: 10.2353/ajpath.2010.100306)

Soft tissues sarcomas (STS) are malignant neoplasms arising from nonepithelial and extraskeletal tissues, such as connective tissue, muscles, vessels, and peripheral nerves. While some sarcomas resemble a specific differentiated tissue (eg, muscle, fat, etc), many are poorly differentiated and their cell of origin remains a debatable topic. Not surprisingly, diagnosis of STS is a difficult task, and few reliable prognostic criteria, mainly based on sarcoma grade and stage, have been identified. ${ }^{1-4}$

During recent years, a concept has been developed that many STS, particularly those without significant presentation of cell lineage-specific markers, may arise from mesenchymal stem cells (MSC). The majority of those studies have been based on MSC derived from the bone marrow. ${ }^{5-8}$ The possibility that STS may develop from bone marrow MSC has been raised by a report that, according to cell lineage tracing experiments in irradiation chimeras, STS arise from bone marrow-derived cells. $^{9}$

Genetically, STS can be divided into two groups. One group has a consistent set of recurrent genetic alterations, such as translocations (eg, PAX3-FOXO1A in alveolar rhabdomyosarcoma) and specific mutations (eg, KIT activating mutation in gastrointestinal stromal tumors). Another group, which comprises the majority of STS, is characterized by complex genomic profiles and frequent presence of mutations in tumor suppressor genes P53 and Retinoblastoma 1 (RB). ${ }^{1-4}$ Further supporting importance of these genes for sarcomagenesis, patients with Li-Fraumeni syndrome, which is associated with germline P53 mutations, as well as patients with germline $R B$ mutation have a higher frequency of STS. ${ }^{2,4}$ In agreement with known cooperation between P53 and RB pathways, mutations in both genes are frequent in STS. ${ }^{10}$ It has been recently reported that conditional Cre-

Supported by grants BK21, Korea and Graduate Research Assistantship awarded by the College of Veterinary Medicine, Cornell University (J.C.) and RR17595 (National Institutes of Health/National Center for Research Resources), CA96823 (National Institutes of Health/National Cancer Institute), and C023050 (New York State Stem Cell Science) awards (A.Y.N.).

Accepted for publication July 19, 2010

Address reprint requests to Alexander Yu. Nikitin, M.D., Ph.D., Department of Biomedical Sciences, Cornell University, T2 014A VRT Campus Road, Ithaca, NY 14853-6401. E-mail: an58@cornell.edu. 
loxP-mediated inactivation of $p 53$ by expression of Osterix-Cre transgene in committed osteoblast progenitors results in formation of osteosarcomas, and loss of $R b$ potentiates osteosarcomagenesis. ${ }^{11-12}$ Similar cooperation between $p 53$ and $R b$ inactivation in acceleration of sarcomagenesis was also observed after expression of Prx1-Cre transgene in mesenchymal cells of mouse embryonic limbs. ${ }^{13}$ In addition to predominant osteosarcoma formation, development of poorly differentiated STS was also reported in that model. However, given that the majority of human STS affect adults, ${ }^{4}$ interpretation of this model has been somewhat complicated due to expression of Prx1-Cre transgene in the early mesenchymal tissues.

By using conditional activation of $K$-ras and inactivation of p53 by intramuscular injection of adenovirus expressing Cre recombinase (AdCMVCre) into adult mice, Kirsch et $\mathrm{al}^{14}$ have established a mouse model of adult high-grade sarcomas with myofibroblastic differentiation. We have used a similar approach for initiation of STS associated with p53 and Rb deficiency by subcutaneous AdCMVCre administration and demonstrate that the majority of these neoplasms are undifferentiated high-grade pleomorphic sarcomas (UPS), also known as malignant fibrous histiocytomas (MFH). Notably, similar to their human counterparts, mouse sarcomas overexpress Cxcr4, and its knockdown results in reduction of invasive properties of sarcoma cells. Based on bone marrow reconstitution experiments we have determined that STS have local as opposed to bone marrow origin. Finally, by using enhanced purification of dermal MSC we have demonstrated that these cells have superior transformation potential and form UPS after $p 53$ and $R b$ inactivation.

\section{Materials and Methods}

\section{Experimental Animals}

Mice with floxed copies of $p 53$ and $R b$ genes were prepared as described previously. ${ }^{15-16} \mathrm{FVB} / \mathrm{N}$ mice were used for controls. Reporter mice Z/EG (Tg(ACTBBgeo/GFP)21Lbe/J; ${ }^{17}$ ), Rosa26Stop ${ }^{\text {IoxP }}$ LacZ (B6;129-

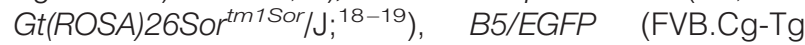
(ACTB-EGPF)B5Nagy/ $/ \mathrm{J}^{20}$ ) and Rosa26LacZ (B6; 129S$\left.\mathrm{Gt}(R O S A) 26 \mathrm{Sor} / \mathrm{J} ;{ }^{21}\right)$ were obtained from the Jackson Laboratory (Bar Harbor, ME). All experiments were conducted under identical conditions, following recommendations of the Institutional Laboratory Animal Use and Care Committee of Cornell University.

\section{Genotyping}

$p 53^{\text {loxP/loxP }}$ and $R b^{\text {loxP/loxP }}$ mice were identified by PCR genotyping essentially as previously described. ${ }^{22}$ Mice carrying $L a c Z$ were detected with PCR primers $L A C Z 5^{\prime}$ (5'-GCGTTGGCAATTTAACCGCCAGTCA-3') and LACZ3' (5'-TCAGCACCGCATCAGCAAGTGTATC-3') yielding 240-bp DNA fragment. Mice carrying EGFP were identified with PCR primers ZEGneo1 (5'-AGAGGCTATTCG-
GCTATGACTG-3') and ZEGneo2 (5'-TTCGTCCAGATCATCCTGATC-3') yielding 430-bp DNA fragment.

\section{Adenovirus Administration}

Recombinant adenoviruses AdCMVLacZ, AdCMVCre, AdCMVeGFP, and AdCMVCre-EGFP are modifications of the adenovirus- 5 genome, from which the ela and elb regions required for viral replication have been deleted and replaced with Escherichia coli-derived LacZ, Cre, or enhanced green fluorescent protein (EGFP) adjacent to the CMV immediate early regulatory sequence ${ }^{23}$ (Gene Transfer Vector Core; University of lowa, lowa City, IA). After deep anesthesia with intraperitoneal (IP) Avertin (2.5\% vol $/ \mathrm{vol}$ in $0.85 \% \mathrm{NaCl} ; 0.02 \mathrm{ml} / \mathrm{g}$ body weight), mice were shaved and adenovirus $\left(5 \times 10^{8} \mathrm{pfu} / \mu \mathrm{l}\right.$ in saline) was injected into the subcutaneous (SC) tissue of the dorsal area with 21-gauge needle under the control of a dissection microscope. The needle was slowly withdrawn to avoid any accidental leak of adenovirus. According to experiments with AdCMVEGFP, AdCMVCre, and C-dots, ${ }^{24}$ as well as evaluation of the early stages of sarcomagenesis (Choi and Nikitin, unpublished), labeled cells were located in the reticular layer of the dermis and in the adjacent loose connective tissue of the hypodermis. Given the continuum of both areas, cells of both regions were used in all experiments and indicated as "dermal" cells.

\section{Generation of Irradiation Chimeras}

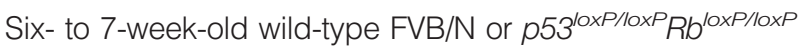
mice were irradiated at $11 \mathrm{~Gy}, 2 \mathrm{~Gy} / \mathrm{min}$ ) by using PRIMUS Linear Accelerator (SIEMENS, Malvern, PA) or a sealed cesium ${ }^{137}$ source irradiator Mark 1-68 (JL Shepherd and Associates, San Fernando, CA). According to the preliminary test experiments, irradiation in both devices resulted in comparable depletion of bone marrow cells. Within 4 hours after irradiation, mice were rescued by tail vein injection of $10^{6}$ bone marrow cells derived from the Z/EG or the Rosa26Stop ${ }^{\text {loxP }}$ LacZ $p 53^{\text {loxP/loxP }}$ B $^{\text {loxP/loxP }}$ mice as described previously. ${ }^{25-26}$ To generate positive control mice, bone marrow cells from B5/EGFP or Rosa26LacZ reporter mice were administrated into irradiated mice. Fourteen days after bone marrow reconstitution, AdCMVCre was administrated subcutaneously into chimeras to induce a sarcoma as described above. In addition to tumor collection, blood for PCR genotyping was collected from the orbital sinus after anesthesia.

To evaluate a proportion of donor bone marrow cells in chimeras, bone marrow cells were collected from the femur and the dermis of chimeras rescued by bone marrow cells from B5/EGFP reporter mice. Bone marrow cells were stained with PerCP-Cy5.5 anti-mouse Gr-1 (\#155931-82, eBioscience, Inc., San Diego, CA) for 30 minutes on ice and then analyzed by a BD LSRII analyzer (BD Biosciences, Franklin Lakes, NJ). All collected data were analyzed by FlowJo software (Tree Star, Inc. Ash- 
land, OR). The skin tissues were fixed in $4 \%$ paraformaldehyde overnight and embedded in paraffin.

\section{Pathological Evaluation}

For long-term survival experiments mice were monitored daily for 600 days, until becoming moribund or until tumor reached $1 \mathrm{~cm}$ in diameter. For short-term experiments, mice were killed at $1,3,7$, and 14 days postadministration of adenovirus. Mice were anesthetized with Avertin and subjected to cardiac perfusion at $90 \mathrm{~mm} \mathrm{Hg}$ with phosphate-buffered $4 \%$ paraformaldehyde. Tumor, skin, lung, liver, and spleen, as well as organs with pathological changes, were examined during necropsy and placed into $4 \%$ paraformaldehyde for postfixation overnight. For short-term experiments with EGFP adenoviruses, the entire dorsal skin from the shoulder to hip was collected and visualized using fluorescence microscopy. Representative specimens were further characterized by microscopic analysis of paraffin sections, cut $4 \mu \mathrm{m}$ thick, and stained with hematoxylin and eosin. All neoplasms were classified according to current histological classification of mouse ${ }^{27}$ and human ${ }^{4}$ STS.

\section{Immunohistochemical Analyses}

For avidin-biotin-peroxidase-based (ABC) detection, deparaffinized and rehydrated sections were subjected to antigen retrieval by either boiling in $10 \mathrm{mmol} / \mathrm{L}$ sodium citrate buffer ( $\mathrm{pH}$ 6.0, 10 minutes) for antibodies to desmin, procollagen type I, EGFP, and CXCR4 or trypsin pretreatment for antibodies to CD31 and F4/80. The antibodies to F4/80 (1:200; \#MCP497G, Serotec, Raleigh, NC), procollagen type I (Y-18; 1:50; \#sc-8787, Santa Cruz Biotechnology, Santa Cruz, CA), CD31 (PECAM-1; 1:100; \#551262, BD Biosciences), smooth muscle actin (1:300; \#E2464, Spring bioscience, Fremont, CA), desmin (1:200; \#YMPS31, Accurate Chemical \& Scientific Corporation, Wesbury, NY), CXCR4 antibody (1:200; \#sC9046, Santa Cruz Biotechnology, Inc., Santa Cruz, CA), $\beta$-galactosidase (1:500; \#ab616-1, Abcam, Cambridge, MA), or EGFP (1:500; \#NB600-303, NOVUS biologicals, Littleton, $\mathrm{CO}$ ) were incubated for 1 hour at room temperature (RT) with the exception of CD31 which was used overnight at $4^{\circ} \mathrm{C}$. The antibody to $\alpha$-sarcomeric actin (1:1500; \#A2172, Sigma, St. Louis, MO) was incubated using MOM Kit (Vector, Burlingame, CA) for 20 minutes at RT. After treatment with $0.3 \% \mathrm{H}_{2} \mathrm{O}_{2}$ in methanol, sections were incubated with biotinylated secondary antibodies and $\mathrm{ABC}$ complex and visualized using 3,3'-diaminobenzidine tetrahydrochloride (DAB) and counterstaining with hematoxylin essentially as described previously. ${ }^{28}$ As a control, primary antibodies were replaced with non-immune sera of the same species.

For immunostaining of human STS tissue arrays (\#BC24011, US Biomax, Inc., Rockville, MD), slides were incubated at $60^{\circ} \mathrm{C}$ for 2 hours according to the manufacturer's instructions and then processed for staining with antibody to CXCR4 as described above. The semiquantitative assessment of staining level was performed as follows: -, no detectable staining; +, $<30 \%$ of cells are positive, ++30 to $60 \%$ of cells are positive,,$+++>60 \%$ of cells are positive.

For double immunofluorescence analysis the deparaffinized sections of $4 \%$ paraformaldehyde-fixed tissue were incubated with rabbit antibodies to $\operatorname{EGFP}(1: 300)$ for 1 hour at $37^{\circ} \mathrm{C}$ or rabbit antibodies to CXCR4 (1:100) or rat antibodies to $F 4 / 80$ (1:100) for 1 hour, RT, followed by Alexa Fluor 488 conjugated donkey anti-rabbit or anti-rat secondary antibody (Invitrogen, Carlsbad, CA) for 30 minutes, RT. Subsequently, goat antibodies to procollagen type I (1:50), Iba-1 (1:200; abcam) or rabbit antibodies to CXCR4 (1:100) were applied for 1 hour, RT, followed by Alexa Fluor 594 conjugated donkey anti-goat or anti-rabbit secondary antibody (Invitrogen) was incubated with sections.

For immunostaining on frozen sections, tissues were frozen in liquid nitrogen with Tissue-Tek (SAKURA, McGaw Park, IL). Seven-micrometer-thick tissue sections were placed onto Superfrost plus-coated slides (Fisher Scientific, Pittsburgh, PA) and fixed in cold acetone $\left(-20^{\circ} \mathrm{C}\right)$ for 10 minutes. Sections were incubated with primary antibody to F4/80 (1:100), Iba-1 (1:200), CD31 (1:100), smooth muscle actin (1:200), and procollagen type I (1:50) at RT for 1 hour or to CD31 (1:100) at $4^{\circ} \mathrm{C}$ overnight followed by secondary antibodies conjugated with Alexa Fluor 594. Counterstaining was performed by incubation for 1 minute with DAPI $(1 \mathrm{mg} / \mathrm{ml}$ of an aqueous solution diluted 1:100 in TBS). Slides were mounted with GEL/MOUNT (Biomeda corp, Foster City, CA) and viewed with a Zeiss LSM 510META confocal microscope.

\section{Cell Culture}

Tissue cultures were maintained using Dulbecco's modification of Eagle's medium (DMEM; Cellgro, Mediatech, Inc., Manassas, VA), containing 10\% heat-inactivated fetal bovine serum (FBS; Sigma), $100 \mathrm{U} / \mathrm{ml}$ penicillin, 100 $\mu \mathrm{g} / \mathrm{ml}$ streptomycin, $2 \mathrm{mmol} / \mathrm{L}$ L-glutamine, and $1 \mathrm{mmol} / \mathrm{L}$ sodium pyruvate (Cellgro, Mediatech, Inc.). Primary fibroblast culture was prepared from tail dermis of adult

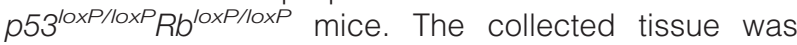
washed three times in $70 \% \mathrm{EtOH}$ and three times in PBS, minced finely, and disaggregated with $0.05 \%$ trypsin/ $0.53 \mathrm{mmol} / \mathrm{L}$ EDTA (Cellgro, Mediatech, Inc.) for 1 hour at $37^{\circ} \mathrm{C}$. The trypsin was removed by centrifugation, and the cells were resuspended in medium. The cells were plated in two 6-cm-diameter tissue culture dishes.

For adenovirus infection adherent or suspension cells were plated at a concentration of $10^{5}$ cells in $3 \mathrm{ml}$ of complete growth medium per well in six-well plates. When cells reached $70 \%$ confluence, they were washed twice with PBS and AdCMVCre or AdCMVEGFP was added at a concentration of $5 \times 10^{8} \mathrm{pfu} / \mathrm{ml}$ in $1 \mathrm{ml}$ of serum free growth medium. After incubation for 2 hours at $37^{\circ} \mathrm{C}$ with $5 \% \mathrm{CO}_{2}$, the virus containing medium was removed and the cells were washed two times with PBS. The cells were given at least 3 days to recover in complete growth medium before use in further assays.

Cell lines STN1 and STN2 were established from angiosarcoma and UPS, respectively, developed in 


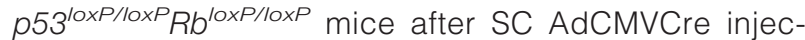
tion. FBN1 cell line was established 40 passages after Cre-loxP-mediated deletion of $p 53$ and $R b$ in plastic adherent dermal cells. Cultures were maintained at $37^{\circ} \mathrm{C}$ and $5 \% \mathrm{CO}_{2}$, and medium replaced every 3-4 days.

\section{Western Blotting}

Cells were lysed in RIPA (25 mmol/L Tris, pH 8.2, 50 $\mathrm{mmol} / \mathrm{L} \mathrm{NaCl}, 0.1 \% \mathrm{SDS}, 0.5 \%$ Nonidet P-40, and 0.5\% deoxycholate) buffer with protease inhibitors as described previously. ${ }^{29}$ Proteins were resolved on SDSPAGE gels and transferred to nitrocellulose via semidry transfer (BioRad, Hercules, CA). Immunoblots were blocked with $5 \%$ milk in TBST for 1 hour and washed three times with fresh TBST. CXCR4 antibody (1:200; \#sc-9046, Santa Cruz Biotechnology, Inc.) was incubated with immunoblots overnight at $4^{\circ} \mathrm{C}$ followed by HRP-conjugated anti-rabbit antibody (1 hour at RT) and detection with SuperSignal West Pico Chemiluminescent Substrate (Pierce Biotechnology, Inc., Rockland, IL).

\section{Cxcr4-siRNA Transfection}

One day before transfection, cells were plated with $2 \mathrm{ml}$ of growth medium without antibiotics in a six-well plate. Cxcr4-siRNA (5 nmol; Accell SMARTpool siRNA, \#E060184-00-0005, Thermo Scientific, Waltham, MA) or control-siRNA oligomers (Accell nontargeting pool, \#D001910-10) was diluted in siRNA buffer (Thermo Scientific) to make a $100 \mu \mathrm{mol} / \mathrm{L}$ siRNA solution. $7.5 \mu \mathrm{l}$ of the $100 \mu \mathrm{mol} / \mathrm{L}$ siRNA was combined with $750 \mu \mathrm{l}$ Accell delivery media (Thermo Scientific), and $100 \mu$ of the appropriate delivery mix was added to each well containing cells with $\sim 50 \%$ of confluence. Cells were incubated at $37^{\circ} \mathrm{C}$ in a $5 \% \mathrm{CO}_{2}$ incubator for 72 hours until using for an invasion assay.

\section{Isolation of Mesenchymal Stem Cells}

Plastic adherent dermal (PAD) cells were prepared from

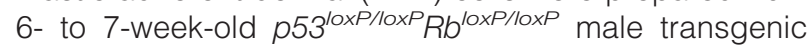
mice according to a protocol by Wilson et $\mathrm{al}^{30}$ with modifications. Briefly, euthanized mice were shaved and treated with Nair (Church \& Dwight Co., Inc., Princeton, $\mathrm{NJ}$ ) before skin removal. Harvested skin was cut into $1-\mathrm{cm}^{2}$ pieces and incubated for 1 hour at $37^{\circ} \mathrm{C}$ in enzyme mix A, consisting of $5 \mathrm{U} / \mathrm{ml}$ dispase (Sigma) and 3\% FBS in PBS. After this, the epidermis was discarded by mechanical dissociation and the remaining tissue was incubated overnight at $4^{\circ} \mathrm{C}$ in enzyme mix $\mathrm{A}$. Tissue was then incubated for 2 hours at $37^{\circ} \mathrm{C}$ in enzyme mix B, consisting of $1.0 \mathrm{U} / \mathrm{ml}$ dispase, $0.13 \mathrm{U} / \mathrm{ml}$ collagenase (Sigma), 700 $\mathrm{U} / \mathrm{ml}$ hyaluronidase (Sigma), and $20 \mathrm{U} / \mathrm{ml}$ DNase I (Sigma) in $1 \times$ PBS. Both enzyme mix A and B were combined and forced through a 70- $\mu \mathrm{m}$ strainer for a single cell suspension. Cells were subsequently plated in complete medium at $5 \times 10^{6}$ cells per $10-\mathrm{cm}$ plate. PAD cells in passage 1 were detached and suspended in antibody staining buffer, consisting of $0.1 \%$ bovine serum albumin
(BSA; Sigma) in PBS. Negative selection was carried out using magnetic Dynalbeads (Invitrogen) with CD31 (Platelet Endothelial Cell Adhesion Molecule-1, PECAM-1) and CD45 (Leukocyte Common Antigen, Ly-5) biotinylated antibodies (\#553371 and \#553077, respectively, BD Biosciences). Cells were incubated at $4^{\circ} \mathrm{C}$ for 30 minutes at a concentration $1 \mu \mathrm{g}$ of antibodies per $10^{6}$ cells, according to the manufacturer's instructions. Supernatant containing CD31- $/ \mathrm{CD} 45^{-}$cells was used for FluorescenceActivated Cell Sorting (FACS) after incubation with fluorescein-conjugated antibodies to Ly-6A/E (\#553335, Sca-1; BD Biosciences) at a concentration of $1 \mu \mathrm{g}$ of antibodies per $10^{6}$ cells at $4^{\circ} \mathrm{C}$, in the dark, for 30 minutes. Appropriate isotype controls were used for accurate gating parameters. FACS was conducted using a FACSAria cell sorter (BD Biosciences).

\section{Differentiation Assay}

Sorted cells in passage three were replated onto six-well plates at a concentration of $5 \times 10^{5}$ cells per well in $3 \mathrm{ml}$ of a complete growth medium. When cells were confluent, medium was removed and replaced with appropriate differentiation or control medium. Control medium consisted of DMEM with $1 \%$ FBS to reduce nonspecific differentiation. Cells were cultured from 6 to 21 days, depending on the assay type, and had medium replaced every 2 days. Adipocyte differentiation medium contains $5 \mu \mathrm{g} / \mathrm{ml}$ insulin (Sigma), $1 \mu \mathrm{mol} / \mathrm{L}$ dexamethasone (Sigma), $0.5 \mathrm{mmol} / \mathrm{L}$ IBMX (Sigma), and 10\% FBS in DMEM:F12 (Cellgro, Mediatech, Inc.). The cells were maintained for 7 days, then fixed with $4 \%$ paraformaldehyde, stained with $0.21 \%$ (wt/vol) Oil Red O (Sigma) in $60 \%$ isopropanol for 10 minutes, and washed with tap water. Chondrocytes were maintained in medium consisting of $200 \mu \mathrm{mol} / \mathrm{L}$ L-ascorbic acid 2-phosphate, 100 $\mathrm{nmol} / \mathrm{L}$ dexamethasone, $10 \mathrm{ng} / \mathrm{ml}$ TGF- $\beta 1$ (R\&D Systems, Minneapolis, MN), $40 \mu \mathrm{g} / \mathrm{ml}$ L-proline (Sigma), 1:100 ITS + Premix (BD Biosciences), and 10\% FBS in DMEM for 14 days. Then, cells were fixed in $2.5 \%$ glutaraldehyde, $25 \mathrm{mmol} / \mathrm{L}$ sodium acetate, and $0.4 \mathrm{~mol} / \mathrm{L}$ $\mathrm{MgCl}_{2}$ containing $0.05 \%$ (wt/vol) Alcian Blue (Sigma) for 48 hours and washed in steps with 3\% acetic acid, 3\% acetic acid $/ 25 \%$ ethanol, and $3 \%$ acetic acid/50\% ethanol. For the osteocyte differentiation assay, cells were cultured in $300 \mu \mathrm{mol} / \mathrm{L}$ L-ascorbic acid 2-phosphate (Sigma), $10 \mathrm{nmol} / \mathrm{L}$ dexamethasone, $10 \mathrm{mmol} / \mathrm{L} \beta$-glycerophosphate (Sigma), and 10\% FBS in DMEM:F12 for 21 days. Then, cells were fixed in $70 \%$ ice-cold ethanol for 1 hour, stained with $2 \%$ (wt/vol) Alizarin Red (Sigma) $\mathrm{pH}$ 4.2 , for 10 minutes, and rinsed with $1 \times$ PBS. Ten random images of each well were taken at $\times 20$ magnification for quantification.

\section{Soft Agar Colony Formation, Invasion, and Tumorigenicity Assays}

All assays were performed as previously described. ${ }^{31-33}$ Briefly, for soft agar colony formation, PAD cells in passage 3 were suspended in an agar mix at $5 \times 10^{5}$ cells 
A

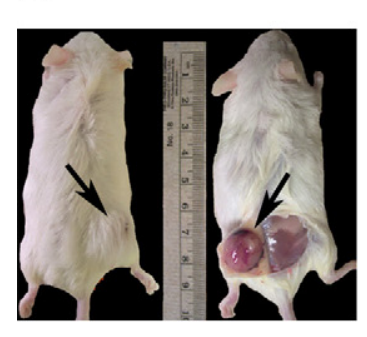

B

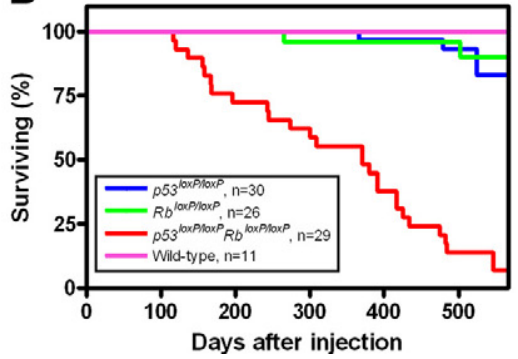

C

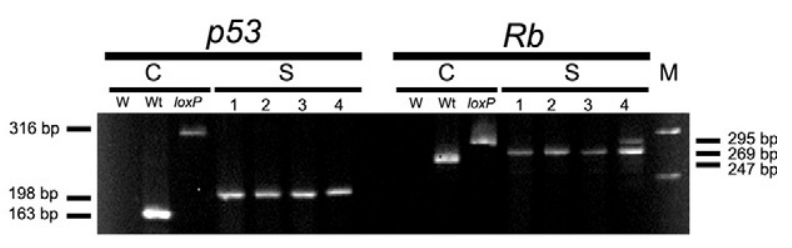

Figure 1. Induction of soft tissue sarcomas by conditional inactivation of $p 53$ and/or $R b$. A: Sarcomas are detected at the site of AdCMVCre (right lower dorsal quadrant, arrow) but not AdCMVLacZ injection (left lower dorsal quadrant) of $p 53^{\text {loxp/loxP }} R b^{\text {loxP/loxP }}$ mice. In the right mouse, a sarcoma mass was flipped over together with attached skin during dissection. B: Survival of wild-type, $p 53^{\text {loxP } / \text { lox } P}, R b^{\text {loxP/loxP }}$, and $p 53^{\text {loxP/loxP }} R b^{\text {loxP/loxP }}$ male mice after a single subcutaneous injection of AdCMVCre. Mice were sacrificed when sarcoma diameter reached $10 \mathrm{~mm}$ in diameter. All remaining mice were euthanized on day 600 . Median survival for $p 53^{\text {loxP/loxP }} R b^{\text {loxP/loxP }}$ mice was 370 days. Compared to wild-type mice, $P$ values for survival curves of $p 53^{\text {loxP/loxP }} R b^{\text {loxP/loxP }}, p 53^{\text {loxP/loxP }}$, and $R b^{\text {loxP } / l o x P}$ mice were $<0.0001,0.4096$, and 0.4616 , respectively. $n$, number of mice in the experimental group. C: Loss of the $p 53$ and $R b$ genes in soft tissue tumors according to PCR analysis. Lanes 1 and 2: STN1 and STN2 cell lines, respectively. Lanes 3 and 4: Cells from primary tumors negatively sorted for F4/80 and CD11b and analyzed one passage (lane 3) and directly after sorting (lane 4). The 295-, 269-, and 247-bp fragments are diagnostic for floxed, excised, and wild-type alleles of the $R b$ gene, respectively. The 585-, 467-, and 432-bp fragments are diagnostic for floxed, excised, and wild-type alleles of the $p 53$ gene, respectively. W, blank control, Wt, wild-type DNA, loxP, DNA with floxed gene, M, DNA marker.

per $6-\mathrm{cm}$ plate and incubated at $37^{\circ} \mathrm{C}$ and $5 \% \quad \mathrm{CO}_{2}$. Analysis was conducted by comparing the number of colonies present in each group after 3 weeks of growth in soft agar. For uniformity, a colony was considered to be a group of four or more cells. For invasion assay, PAD cells in passage 3 or tumor cells were placed into Matrigel Invasion Chambers (BD Biosciences, Franklin Lakes, NJ) at concentration $2.5 \times 10^{4}$ cells per well. For PAD cells, complete medium was added in each chamber. For tumor cells treated with either Cxcr4-siRNA or scrambled siRNA, 400 ng of Sdf-1 (R\&D Systems, Inc.) in serum-free medium was added in lower chamber. The plates were then incubated for 22 hours at $37^{\circ} \mathrm{C}$ and $5 \% \mathrm{CO}_{2}$, and invasion ability was determined by comparing cell number on the bottom of control and invasion wells, respectively, to the original plated density. For tumorigenicity assay, $10^{6}$ PAD cells in passage 3 were injected subcutaneously into 7-week-old male SCID/NCr mice (Animal production program, NCl-Frederick, Frederick, MD), and monitoring of tumor growth and tumor collection were performed as described under Pathological Evaluation.

\section{Statistical Analyses}

All statistical analyses were performed with the programs InStat 3.05 and Prism 4.03 (GraphPad, Inc. San Diego,
CA). Survival fractions were calculated using the KaplanMeier method. Survival curves were compared by log rank Mantel-Haenszel tests. Means were compared by estimation of the two-tailed $P$ value.

\section{Results \\ Conditional Inactivation of p53 and Rb in Dermal Connective Tissue Cells Results in Formation of Soft Tissue Tumors}

To test whether inactivation of $p 53$ and/or $R b$ induces soft tissue sarcomas, AdCMVCre was subcutaneously injected into the right lower dorsal quadrant of wild-type or $p 53^{\text {loxP/loxP }}$ and/or $R b^{\text {loxP/loxP }}$ adult male mice. By 600 days of age, three of 30 p53/oxp/loxp mice (10\%) and two of $26 R b^{\text {loxP/loxp }}$ mice $(8 \%)$ developed subcutaneous tumors (Figure 1A and Table 1). At the same time, tumors were formed in 27 of 29 (93\%) p53 ${ }^{\text {loxP/loxP }} R b^{\text {loxP/loxP }}$ mice starting at 116 days postinjection. After initial detection of a small, hard mass on the site of injection, tumors developed rapidly and aggressively over a period of 1 to 2 weeks and frequently showed ulceration, necrosis, hemorrhage, and decreased survival. No tumors were found in the place of AdCMVLacZ injection, the left lower dorsal quadrant of the same mice. Similarly, no tumors were

Table 1. Soft Tissue Sarcomas Induced by a Single Subcutaneous Injection of AdCMVCre into Mice Carrying floxed $p 53$ and/or $R b$

\begin{tabular}{|c|c|c|c|c|}
\hline Genotype & $p 53^{\text {loxP/loxp }}$ & $R b^{10 \times P / / 0 \times P}$ & $p 53^{\text {IoxP/loxP }} R b^{\text {loxP/loxP }}$ & Wild-type \\
\hline Mice with neoplasms, total, \%* & $9.1(3 / 33)^{\dagger}$ & $7.7(2 / 31)$ & $93(27 / 29)$ & $0(0 / 19)$ \\
\hline UPS, $\%^{\ddagger}$ & $33.3(1 / 3)$ & $0(0 / 2)$ & $70(19 / 27)$ & $0(0 / 0)$ \\
\hline Leiomyosarcoma, \% & $33.3(1 / 3)$ & $0(0 / 2)$ & $11(3 / 27)$ & $0(0 / 0)$ \\
\hline Rhabdomyosarcoma, \% & $33.3(1 / 3)$ & $0(0 / 2)$ & $7(2 / 27)$ & $0(0 / 0)$ \\
\hline Angiosarcoma, \% & $0(0 / 3)$ & $50(1 / 2)$ & $4(1 / 27)$ & $0(0 / 0)$ \\
\hline Histocytic sarcoma, \% & $0(0 / 3)$ & $0(0 / 2)$ & $4(1 / 27)$ & $0(0 / 0)$ \\
\hline Fibrosarcoma, \% & $0(0 / 3)$ & $0(0 / 2)$ & $4(1 / 27)$ & $0(0 / 0)$ \\
\hline Dermatofibroma, \% & $0(0 / 3)$ & $50(1 / 2)$ & $0(0 / 27)$ & $0(0 / 0)$ \\
\hline
\end{tabular}

*Numbers in parentheses indicate number of mice with neoplasm of total number of mice.

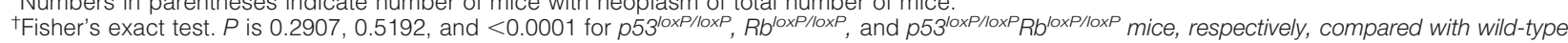
mice.

¥Numbers in parentheses indicate number of particular neoplasm of total number of neoplasms. 
A
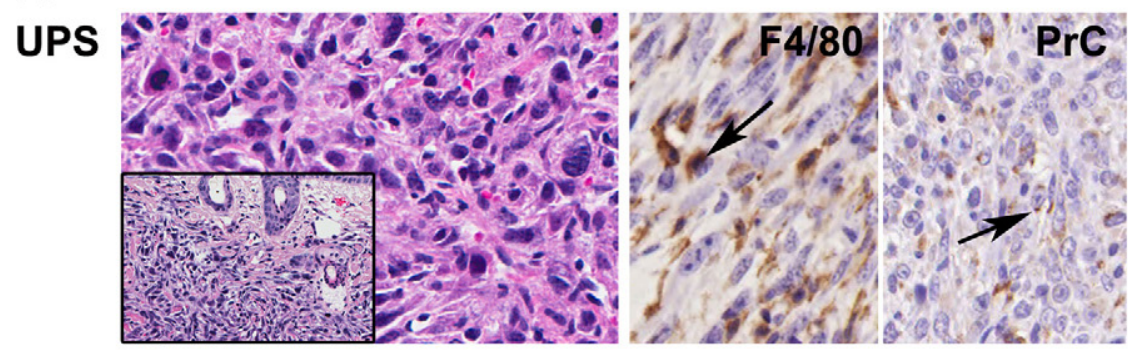

LS
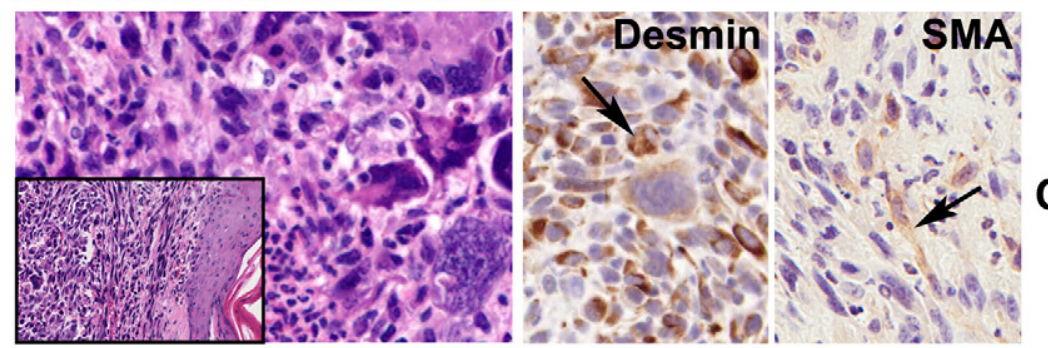

RS
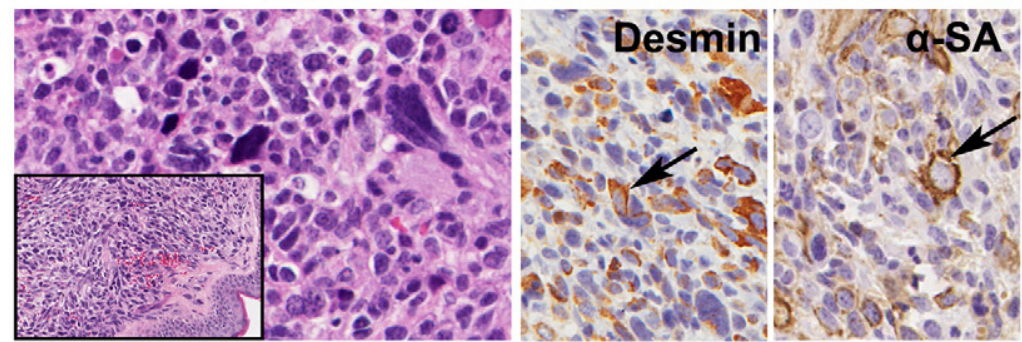

AS
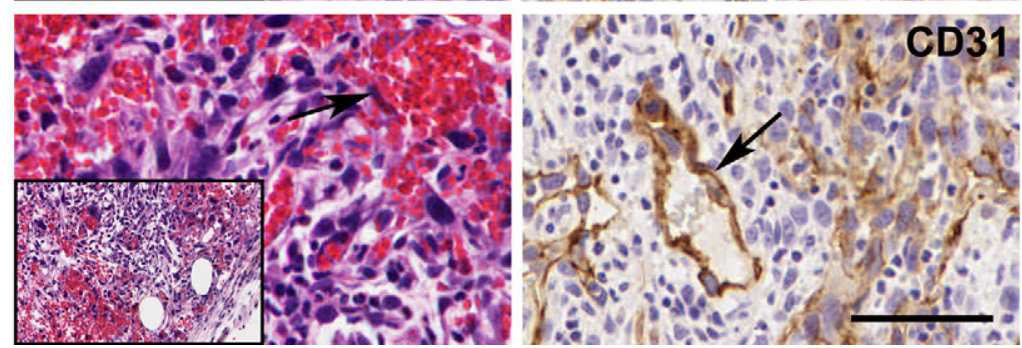

B

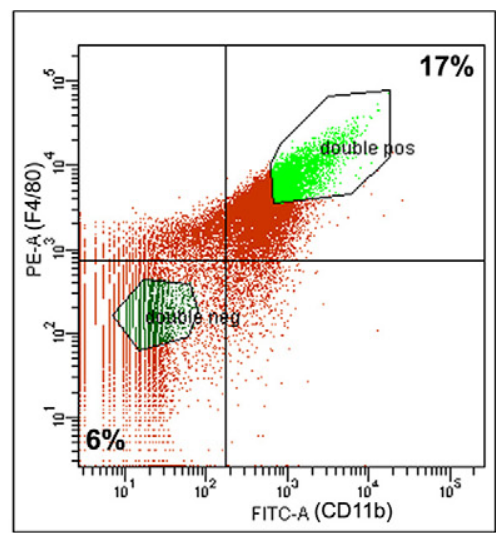

\section{C}

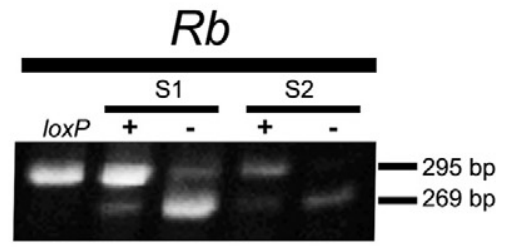

Figure 2. Characterization of soft tissue sarcomas. A: Pathology of soft tissue sarcomas induced by $p 53$ and/or $R b$ inactivation. Expression (arrows, brown color) of $\mathrm{F} 4 / 80$ and procollagen type $\mathrm{I}(\mathrm{PrC})$, desmin, smooth muscle actin (SMA), $\alpha$-sarcomeric actin $(\alpha$-SA), and CD31 in undifferentiated high-grade pleomorphic sarcoma (UPS), leiomyosarcoma (LS), rhabdomyosarcoma (RS), and angiosarcoma (AS). AS features endothelial nuclear atypia (arrow). Hematoxylin and eosin (left column images), and ABC Elite method with hematoxylin counterstaining (right column images) Calibration bar $=50 \mu \mathrm{m}$ (all large images), $20 \mu \mathrm{m}$ (all insets). B: Gating of STS cells positive (double pos, $17 \%$ ) or negative (double neg, 6\%) for F $4 / 80$ (PE) and CD11b (FITC) during FACS based isolation. C: Detection of Cre-loxP-mediated deletion of the $R b$ gene by $\mathrm{PCR}$ in $\mathrm{F} 4 / 80+\mathrm{CD} 11 \mathrm{~b}+(+)$ and F4/80-CD $11 \mathrm{~b}-(-)$ cell subpopulations isolated by FACS from primary STS. loxP, DNA with floxed gene, $\mathrm{S} 1$ and $\mathrm{S} 2$ indicate representative individual tumor samples. See Figure 1 for description of PCR fragments. found in wild-type mice injected with AdCMVCre. PCR genotyping of primary cells, as well as established cell

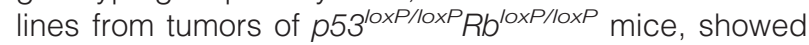
deletion of both $p 53$ and $R b$ (Figure 1C).

\section{Characterization of Soft Tissue Sarcomas}

The majority of tumors were high-grade pleomorphic sarcomas and contained highly variable areas consisting of plump spindle cells intermixed with more polygonal or round, frequently giant cells with hyperchromatic irregular nuclei (Figure 2A). Multiple mitotic figures and some apoptotic cells were observed and the stroma consisted of delicate collagen fibrils encircling individual cells. Invasion of surrounding tissues was commonly observed and pulmonary metastasis were detected in 1 of $3(33 \%)$ and 7 of $29(24 \%)$ sarcomas of $p 53^{\text {loxp/loxp }}$ and $p 53^{\text {loxp/loxp }} R b^{\text {loxp/loxp }}$ mice, respectively. Few neoplasms had distinct histological features consistent with angiosarcoma, histiocytic sarcoma, fibrosarcoma, and dermatofibroma (Table 1). Angiosarcoma and histiocytic sarcoma, respectively expressed markers of endothelial (CD31) and histiocytic (F4/80) differentiation.

According to immunohistochemical analysis significant areas of desmin and either smooth muscle actin or $\alpha$-sarcomeric actin were detected in several pleomorphic sarcomas which were respectively classified as leiomyosarcoma and rhabdomyosarcoma. However, $70 \%$ of sar-

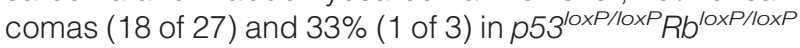
and $p 53^{\text {loxP/loxP }}$ mice, respectively, did not demonstrate any significant (more than 5\%) differentiation with an exception of procollagen type I, a marker of collagen producing cells, such as fibroblasts. Additionally, sarcomas frequently contained a significant number of cells expressing the macrophage marker F4/80 (Figure 2A). However, these cells did not have neoplastic morphology. Consistently, macrophage population selected by fluorescence-activated cell sorting with antibodies to F4/80 and CD11b, contained only traces of Cre-loxP mediated deletion of the $R b$ gene (Figure 2, B and $\mathrm{C}$ ), likely due to phagocytosis of neoplastic cells and/or presence of contaminating neoplastic cells. 
Table 2. Expression of CXCR4 in Human Soft Tissue Tumors

\begin{tabular}{|c|c|c|c|c|}
\hline \multirow[b]{2}{*}{ Tumor type } & \multicolumn{4}{|c|}{ Frequency of tumors with specific level of staining, \%* } \\
\hline & - & + & ++ & +++ \\
\hline UPS & $26.7(4 / 15)$ & $20(3 / 15)$ & $46.7(7 / 15)$ & $6.7(1 / 15)$ \\
\hline Fibrosarcoma & $28.6(2 / 7)$ & $42.9(3 / 7)$ & $28.6(2 / 7)$ & $0(0 / 7)$ \\
\hline $\mathrm{DFSP}^{+}$ & $100(5 / 5)$ & $0(0 / 5)$ & $0(0 / 5)$ & $0(0 / 5)$ \\
\hline Neurofibrosarcoma & $50(2 / 4)$ & $25(1 / 4)$ & $25(1 / 4)$ & $0(0 / 4)$ \\
\hline Liposarcoma & $18.8(3 / 16)$ & $50(8 / 16)$ & $31.3(5 / 16)$ & $0(0 / 16)$ \\
\hline Leiomyosarcoma & $18.2(2 / 11)$ & $18.2(2 / 11)$ & $45.5(5 / 11)$ & $18.2(2 / 11)$ \\
\hline Rhabdomyosarcoma & $0(0 / 1)$ & $100(1 / 1)$ & $0(0 / 1)$ & $0(0 / 1)$ \\
\hline Hemangiosarcoma & $0(0 / 1)$ & $0(0 / 1)$ & $0(0 / 1)$ & $100(1 / 1)$ \\
\hline M. Schwannoma & $100(1 / 1)$ & $0(0 / 1)$ & $0(0 / 1)$ & $0(0 / 1)$ \\
\hline
\end{tabular}

${ }^{*}$ Numbers in parentheses indicate number of particular tumors with specific level of CXCR4 expression of total number of neoplasms of the same type.

†Expression CXCR4 is significantly lower in dermatofibrosarcoma protuberance (DFSP) compared with UPS (Fisher's exact test, $P=0.0081$ ) and leiomyosarcoma (Fisher's exact test, $P=0.0048$ ).

\section{CXCR4 Overexpression Contributes to Invasive Properties of STS}

It has been reported that the expression of CXCR4 in human STSs is associated with poor prognosis and metastasis, ${ }^{34}$ particularly in malignant nonround cell tumors such as UPS and leiomyosarcoma. In agreement with these observations, we determined high expression of CXCR4 in human UPS (MFH) and leiomyosarcoma (Table 2). Notably, we observed that expression of CXCR4 was high in UPS, moderate in fibrosarcoma, and negligible in dermatofibrosarcoma protuberans (Figure 3A).

Consistent with observations in human STS, mouse sarcomas expressed $\mathrm{Cxcr} 4$ according to immunostaining

\section{A}
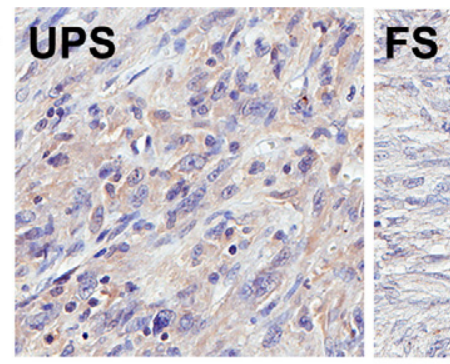

B

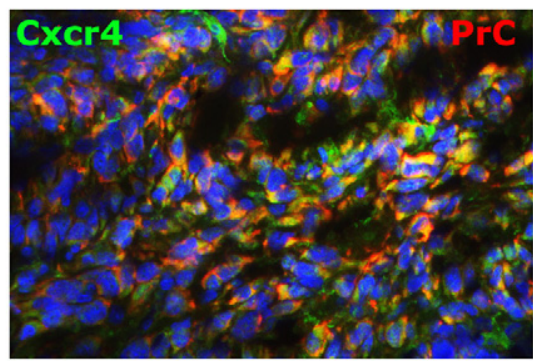

C

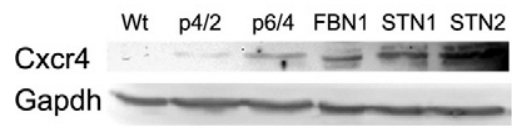

\section{D}

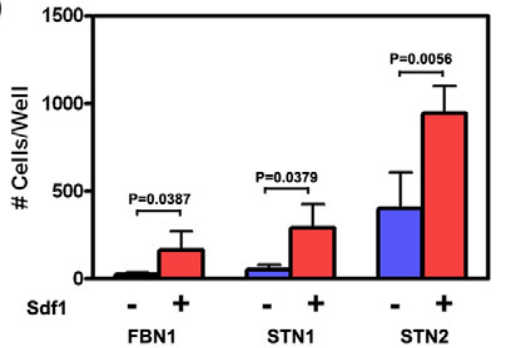

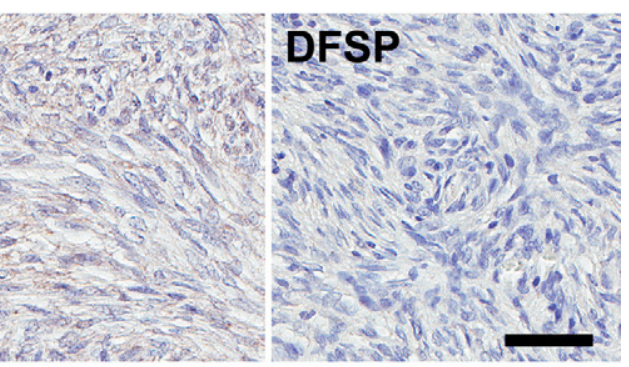
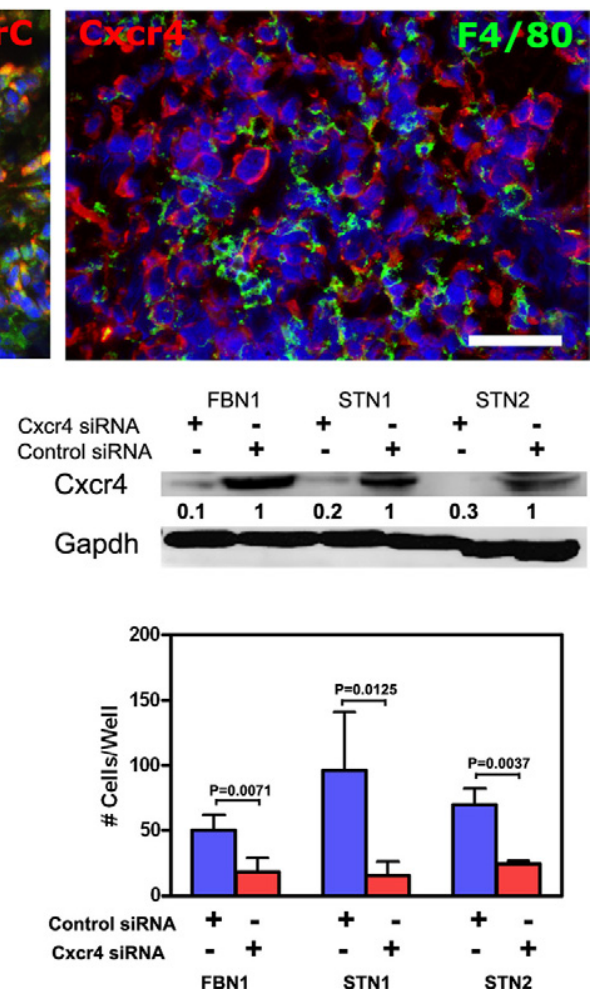

Figure 3. CXCR4 overexpression contributes to invasive properties of STS. A: CXCR4 expression (brown color) in human undifferentiated, highgrade sarcoma (UPS), fibrosarcoma (FS), and dermatofibrosarcoma protuberans (DFSP). Note preferential expression of CXCR4 in UPS. ABC Elite method with hematoxylin counterstaining. B: Colocalization (yellow color) of Cxcr4 expression in cells containing procollagen type I ( $\mathrm{PrC})$ but not F4/80. Double immunofluorescence with DAPI counterstaining. A and B: Calibration bar $=50 \mu \mathrm{m}$. C, Left: Cxcr4 expression in wildtype (Wt) and $p 53^{\text {loxP/loxP }} R b^{\text {loxP/loxP }}$ fibroblasts two (p4/2) and four (p6/4) passages after exposure to AdCMVCre, and in established cell lines FBN1 (passage 43), STN1 and STN2 (both passage 39). Right: Cxcr4 expression after exposure of cell lines FBN1, STN1, and STN2 to Cxcr4 or control siRNA. D: Effects of Sdf1 (left) and siRNA-mediated knockdown of Cxcr4 (right) on cell invasion in Matrigel assay. All values are the mean $\pm \mathrm{SD}, n=4$ (FVBN1 and STN1) or $n=3$ (STN2). Control siRNA, scrambled siRNA. 
Table 3. Percentage of EGFP-Expressing Cells in Dermal Cell Populations 3 Days after AdCMVCre-EGFP Infection

\begin{tabular}{cccccc}
\hline Cell marker & Pro-collagen type I & F4/80 & Iba-1 & Smooth muscle actin & CD31 \\
\hline Mean \pm SD $(\%)^{*}$ & $38.88 \pm 18.77$ & $44.33 \pm 14.38$ & $42.28 \pm 6.53$ & $32.8 \pm 33.37$ & $15.66 \pm 26.46$ \\
\hline
\end{tabular}

${ }^{*}$ At least 50 DAPI-stained cells per field were counted in 10 fields at magnification $\times 400$.

and Western blot analyses (Figure 3, B and C). The majority of $\mathrm{Cxcr} 4$ expressing cells also expressed procollagen type I but not macrophage marker F4/80. Levels of CXCR4 were negligible in primary fibroblast cell cultures but increased after inactivation of $p 53$ and $R b$. To test whether Cxcr4 plays role in sarcoma progression, Matrigel invasion assays were performed with STS cell lines STN1 and STN2 as well as p53 and Rb-deficient fibroblastic cell line FBN1. Cells of all lines showed increased invasion after addition of Cxcr4 ligand Sdf-1 (Figure 3D). At the same time, siRNA-mediated knockdown of $\mathrm{Cxcr} 4$ significantly reduced invasion activity of these cells (Figure 3D).

\section{Connective Tissue Cells Targeted with Adenovirus}

To establish which dermal cells were targeted by adenovirus, expression of EGFP was detected within 1 to 14 days after subcutaneous injection of adenovirus expressing Cre-EGFP (AdCMVCre-EGFP). EGFP expression in subcutaneous tissues was strongest at 1 and 3 days after infection. According to cell phenotyping, 39\% of fibroblasts (procollagen type I+), $44 \%(\mathrm{~F} 4 / 80+)$ or $42 \%$ (Iba$1+)$ of macrophages, $33 \%$ of smooth muscle cells (smooth muscle actin + ), and $16 \%$ of endothelial cells $(\mathrm{CD} 31+)$ were labeled with AdCMVCre-EGFP (Table 3 and Figure $4 \mathrm{~A}$ ).

To test whether adenovirus also infected MSC, this population was isolated from dissociated dermal cells by strict plastic adhesion followed by negative selection for CD45, a marker for cells of hematopoietic origin, including hematopoietic stem cells, and for endothelial cell marker CD31 and positive selection for Sca-1 expression (Figure 4B). Although all plastic adherent cells had a potential for differentiation toward adipogenic and osteogenic differentiation, ${ }^{35}$ our studies demonstrated that further selection for Sca-1 $1^{\text {low }}$ fraction results in additional enrichment for cells with enhanced ability to form adipocytes, chondrocytes and osteocytes (Figure 4C). All cell subpopulations of plastic adherent cells were equally well infected with AdCMVEGFP (Figure 4D).

\section{Local Origin of STS}

To discriminate between bone marrow and local dermal cell of origin of STS, irradiation chimeras reconstituted with donor-derived bone marrow cells isolated from mice with reporter transgenes were generated (Figure 5).

To evaluate a proportion of donor bone marrow cells, bone marrow cells and the dermal cells were evaluated for EGFP expression at 1, 3, 7, and 14 days after irradiation and transplantation of bone marrow cells from B5/
EGFP reporter mice. Reduced numbers of cells expressing Gr-1, a marker for granulocytes and monocytes, and limited EGFP expression was detected at 1 and 3 days after irradiation followed by immediate bone marrow transplantation (Figure 6A). Both cell populations increased by day 7 and were within normal range for a B5/EGFP reporter mouse. These results were consistent with detection of EGFP transgene copy numbers similar to those in B5/EGFP mice by multiplex PCR (Figure 6B). At the same time, $24 \%$ of $\mathrm{Iba}-1+$ macrophages (98.5 \pm 29 , Mean $\pm S D$, out of $410 \pm 86.3$ counted) expressed EGFP 14 days postirradiation (Figure 6C).

To determine whether any STS developed from bone marrow-derived cells, sarcomas were initiated by a single subcutaneous injection of AdCMVCre into irradiated p53 ${ }^{\text {IOXP/loxP }} R b^{\text {IOXP/loxP }}(n=29)$ and wild-type mice $(n=9)$ reconstituted with bone marrow from mice carrying floxed p53 and Rb as well as Rosa26Stop ${ }^{\text {IoxP }}$ LacZ or Z/EG reporter constructs. In these reporter constructs, expression of $\beta$-galactosidase or EGFP, respectively, is possible only after deletion of a STOP codon flanked by loxP sites. Additionally, another group of $p 53^{\text {loxP/loxP }} R b^{\text {loxP/loxP }}$ mice $(n=4)$ was reconstituted with bone marrow of mice carrying constitutively expressed EGFP (B5/EGFP) or LacZ (Rosa26LacZ) transgene. In parallel with collecting tumors, blood from each chimera was collected and genotyped by PCR analysis to confirm the reconstitution with donor cells.

All chimeric mice with host $p 53^{\text {loxP/loxP }} R b^{\text {loxP/loxP }}$ genotype $(n=33)$ but none of wild-type $(n=9)$ developed sarcomas independently of the type of donor mouse strain. The sarcomas were diagnosed as UPS similar to the majority of sarcomas associated with p53 and Rb deficiency. The immunohistochemistry results showed that tumors from control chimeras rescued with bone marrow of mice carrying constitutively expressed EGFP (B5/EGFP) or LacZ (Rosa26LacZ) transgene contained numerous cells expressing EGFP or $\beta$-galactosidase (Figure 7A). These cells did not have atypical cytological features and expressed macrophage marker F4/80 but no procollagen type I (Figure 7B). At the same time, sarcomas developed from chimeras that contain bone marrow cells from the Z/EG $(n=19)$ or the Rosa26STOP ${ }^{\text {oxP }} \operatorname{Lac} Z(n=10)$ reporter mice did not show any GFP or $\beta$-galactosidase expression (Figure 7A). Thus none of the 38 mice developed STS from bone marrow with floxed p53 and $R b$. Taken together with complete reconstitution of bone marrow cells and $24 \%$ reconstitution of the dermal macrophage population, these results indicate that STS associated with $p 53$ and $R b$ inactivation most likely originate from the local resident cells as opposed to bone marrow derived cells, such as macrophages. 

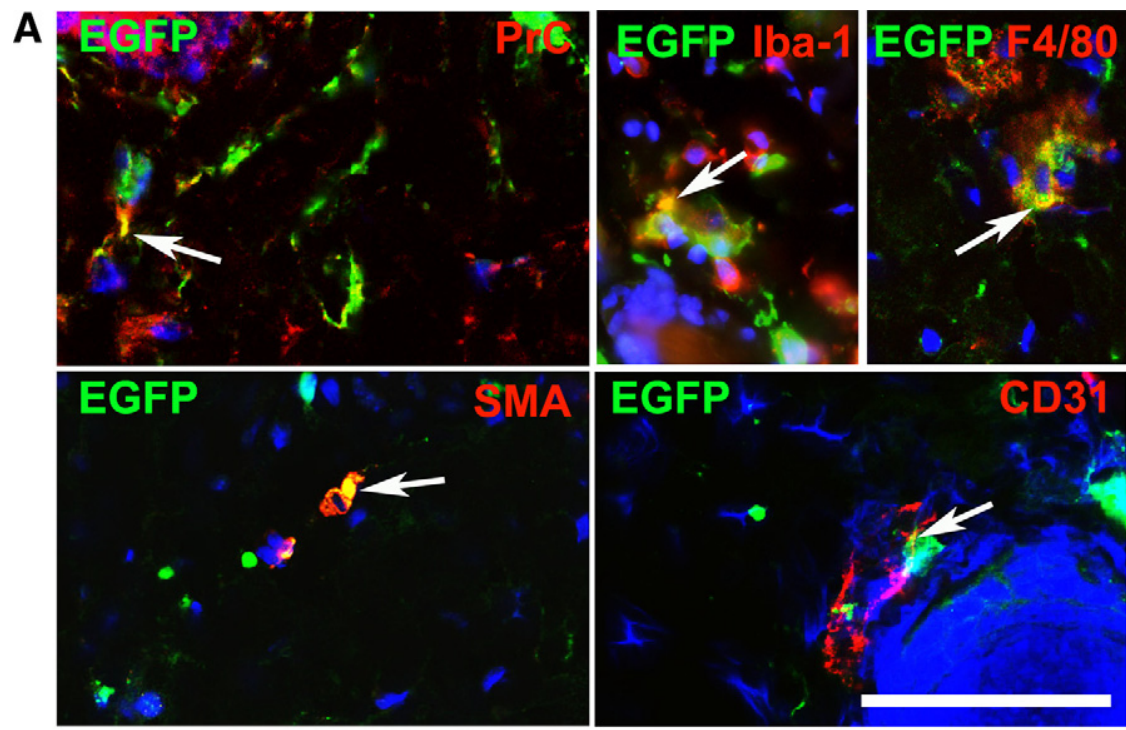

B

C

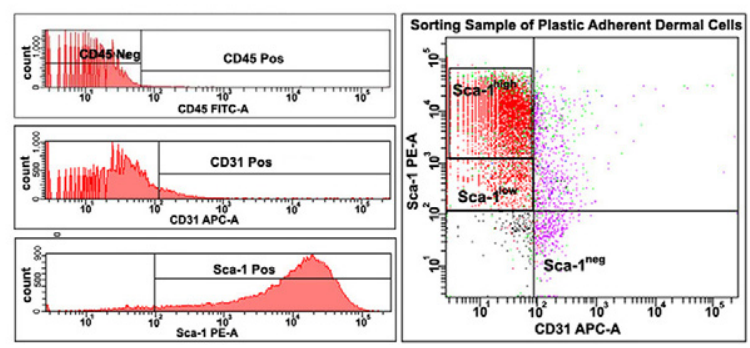

D

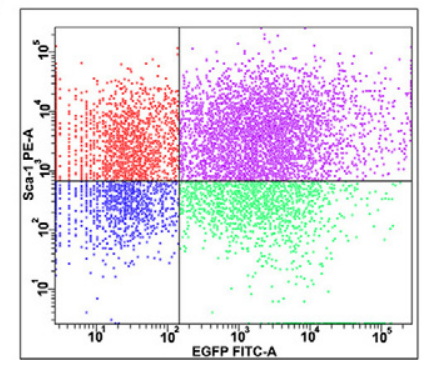

\section{MSC Have Enhanced Potential for Malignant Transformation}

To investigate whether dermal MSC could be a target for malignant transformation in our model, these cells were subjected to a series of transformation-related assays after AdCMVCre-mediated inactivation of $p 53$ and $R b$. First, the ability of the three plastic adherent dermal cell populations to form colonies in soft agar was compared. Interestingly, Sca-1 $1^{\text {low }}$ cells showed an increase in the number of colonies when compared to the other 2 plastic adherent dermal cell populations (Figure 8A). Secondly, invasion ability of transformed plastic adherent dermal cells among Sca- $1^{\text {neg }}$, Sca- $1^{\text {low }}$, and Sca- $1^{\text {high }}$ populations was tested using a Matrigel invasion chamber. Sca$1^{\text {low }}$ cells once again exhibited the greatest potential for malignant transformation compared to the other two plastic adherent dermal cell populations (Figure 8A). Finally, tumorigenicity of MSC was tested after their subcutane-
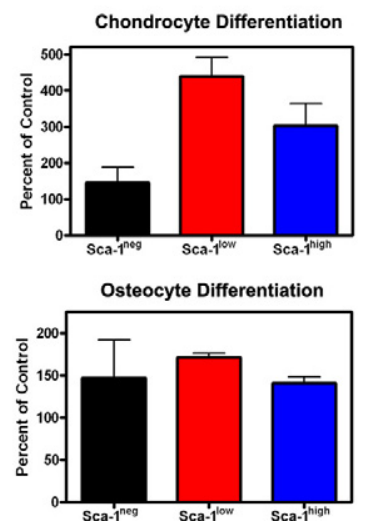

Figure 4. Identification of connective tissue cells infected with AdCMVCre-EGFP adenovirus. A: Colocalization (yellow color, arrows) of EGFP and fibroblastic (procollagen type I, PrC), macrophage (F4/80), smooth muscle (smooth muscle actin, SMA), or endothelial (CD31) markers. Calibration bar $=50 \mu \mathrm{m}$. B: Expression of CD 45, CD31, and Sca-1 in plastic adherent dermal cells (left). Sorting gates for isolation of Sca- $1^{\text {high }}$, Sca- $^{\text {low }}$, and Sca- $1^{\text {neg }}$ cell populations after negative selection for CD45 and CD31 (right). C: $\mathrm{Sca}-1^{\text {low }}$ cells have a greater potential for differentiation into adipocytes $(P=0.0076)$, chondrocytes $(P=0.0139)$, and osteocytes $(P=$ $0.0006)$ compared with Sca- $1^{\text {high }}$ population. Additionally, Sca- $1^{\text {low }}$ cells have greater adipocyte $(P=0.0001)$ and chondrocyte $(P=0.0001)$ potential compared with Sca- $1^{\text {neg }}$ cells. Values (mean $\pm \mathrm{SD}, n=4$ ) represent percentage of controls without differentiation medium. All experiments were repeated at least twice and subjected to unpaired $t$-tests with two-tailed $P$ values. D: Flow cytometry analysis of expression of Sca-1 ( $y$ axis) and EGFP ( $x$ axis) 1 week after infection of dermal plastic adherent cells with adenovirus expressing EGFP. ous transplantation into SCID mice. Sca- $1^{\text {low }}$ cells formed tumors faster (Figure 8B). Importantly, tumors were UPS histologically similar to conditionally induced sarcomas in

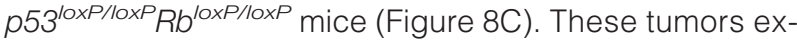
pressed procollagen type I but no other diagnostic markers in neoplastic cells, including desmin (Figure $8 \mathrm{C})$. These results indicate that Sca-1 $1^{\text {low }}$ multipotent dermal stem/progenitor cells are a preferential target for malignant transformation associated with p53 and $R b$ deficiency.

\section{Discussion}

STS are relatively uncommon neoplasms and constitute less than $1 \%$ of all cancers, with an estimated 10,660 new STSs diagnoses and 3820 related deaths in 2009. ${ }^{36} \mathrm{How}-$ ever, lack of identifiable precursor lesions and high heterogeneity of these neoplasms, as well as incomplete 
Lethal dose of irradiation (11Gy)

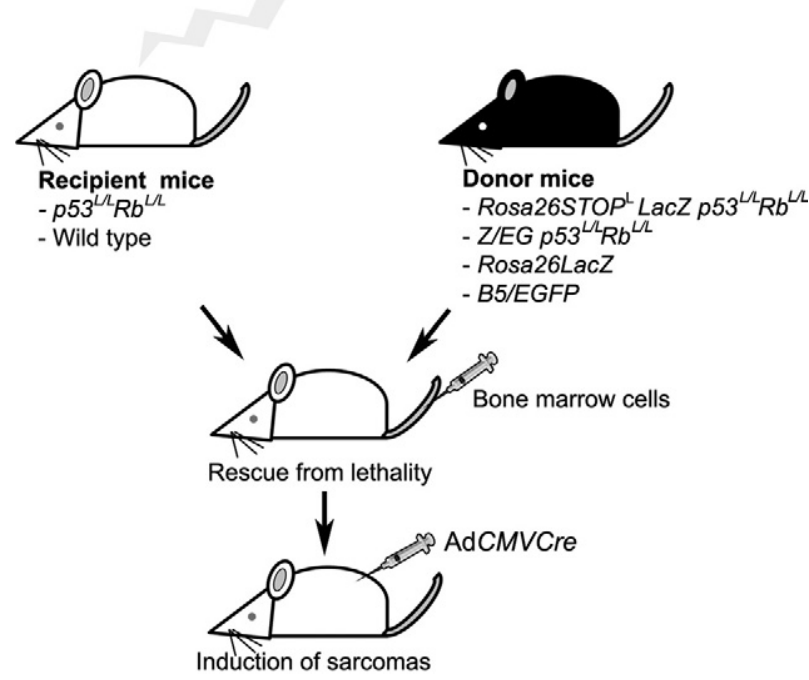

Figure 5. Identification of soft tissue sarcoma cellular origin in irradiation chimeras. $p 53^{\text {loxP/loxP }} R b^{\text {loxP/loxP }}\left(p 53^{L / L} R b^{L / L}\right)$ or wild-type mice were exposed to lethal dose (11 Gy) of irradiation, followed by rescue with bone marrow cells derived from the Rosa26Stop ${ }^{\text {loxP }}$ LacZ (Rosa26Stop ${ }^{L} L a C Z$ ) or the $\mathrm{Z} / \mathrm{EG}$ reporter mice containing either wild-type or floxed $p 53$ and $R b$. Soft tissue sarcomas were induced by the subcutaneous AdCMVCre injection 14 days after bone marrow reconstitution.

understanding of ontogenesis and phenotypical plasticity of normal connective tissue cells represent a continuous challenge for diagnosis, which is reflected in continuous shift in STS classifications. Therefore, development of mouse models which accurately recapitulate both morphological features and frequent genetic alterations of human STS is of critical importance. The mouse model of STS reported here addresses this need because histology of induced sarcomas is similar to those of human STS. Furthermore, mutations in p53 and $R b$ are the most common genetic alterations occurring in sarcomas with complex genotype, such as UPS, fibrosarcoma, and leiomyosarcoma.

Similarity between human STS and sarcomas in our mouse model was further confirmed by observation of expression of CXCR4 which is a receptor of chemokine CXCL12 (SDF-1 $\alpha$ ). It has been previously reported that signaling through CXCR4 plays an important role in progression of a broad variety of malignancies, including breast cancers, ${ }^{37}$ prostate cancers, ${ }^{38}$ malignant melanomas, ${ }^{37,39}$ gastric cancer, ${ }^{40}$ osteosarcomas, ${ }^{41}$ and rhabdomyosarcomas. ${ }^{42}$ In agreement with a previous report that expression of CXCR4 is associated with poor prognosis of STS ${ }^{34}$ we observed that expression of CXCR4 is significantly higher in high-grade sarcomas, such as UPS and leiomyosarcomas as compared to low-grade dermatofibrosarcoma and fibrosarcoma. Furthermore, according to our Matrigel invasion assays, stimulation of Cxcr4 by addition of Sdf-1 increased invasion of sarcoma cells, while siRNA-mediated knockdown of Cxcr4 significantly reduced their invasion. Taken together, these results demonstrate that the CXCR4/SDF-1 axis is an important mediator in sarcoma progression. It has been reported that CXCR4 expression is repressed by $\mathrm{p} 53 .{ }^{43}$ Our observations of increased $\mathrm{Cxcr} 4$ expression in fibro-
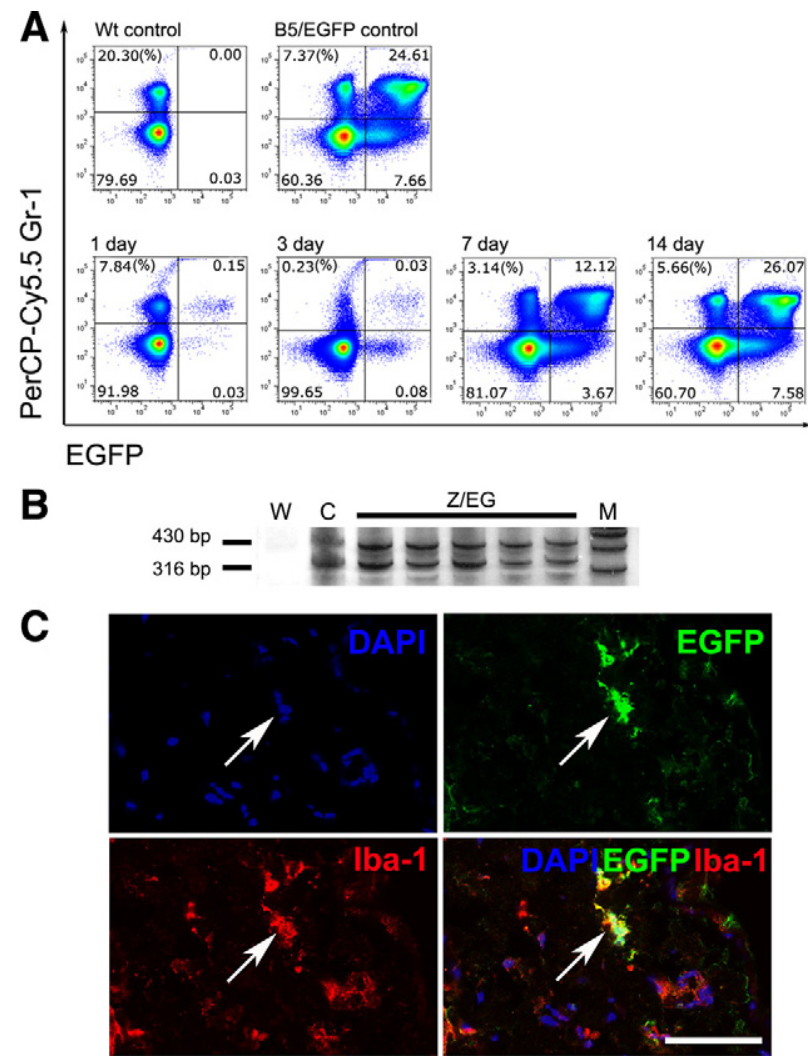

Figure 6. Assessment of bone marrow rescue in irradiation chimeras. A: Efficiency of reconstitution of bone marrow cells according to coexpression of donor-derived EGFP and granulocyte/monocyte marker Gr-1 between 1 and 14 days after irradiation and transplantation of bone marrow from $B 5 / E G F P$ mice (lower row). Wt and B5/EGFP, Gr-1/EGFP profiles of bone marrow cells from wild-type and $B 5 / E G F P$ mice, respectively (upper row). B: Detection of ACTBStop ${ }^{\text {loxP }}$ EGFP transgene $(430 \mathrm{bp}$ ) by PCR analysis of blood from chimeras that were transplanted with bone marrow cells from the Z/EG reporter mice. The 316-bp DNA fragment diagnostic of floxed p53 was used as internal reference control. (W, water control; C, DNA from a mouse carrying the $Z / E G$ reporter, as well as floxed $p 53$ and $R b$ genes; M, marker). Silver staining of acrylamide gels. C: Coexpression of EGFP and macrophage marker Iba-1 in dermal cells 14 days after irradiation and transplantation of bone marrow cell-derived B5/EGFP donor mice. DAPI counterstaining. Arrows indicate the same area in all images. Calibration bar $=50 \mu \mathrm{m}$.

blasts after $p 53$ and $R b$ inactivation is consistent with that report and indicate that inactivation of p53 during sarcoma initiation may predetermine some of the advanced metastatic traits.

Diagnosis of UPS, also known as MFH, is a matter of a particular controversy. Given the lack of specific immunohistochemical markers and firm diagnostic criteria of this neoplasm, it is not surprising that the frequency of UPS/MFH diagnosis ranges from $5 \%$ to $70 \% .^{3-4,44} \mathrm{MFH}$ was originally described by A. P. Stout and colleagues ${ }^{45-47}$ as a neoplasm consisting of histiocyte-like and fibroblast-like cells. Some initial studies performed on human cells and tissues, as well as in transplantation experiments, have supported an origin of these sarcomas from bone marrow-derived cells of the mononuclear phagocyte system, that is histiocytes/ macrophages. ${ }^{46,48-53}$ However, later observations based on advanced ultrastructural and immunohistochemical characterization of neoplastic cells, as well as studies of sequential evaluation of sarcoma formation in rats and 
A $\beta$-gal

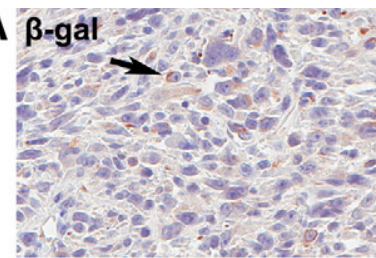

EGFP

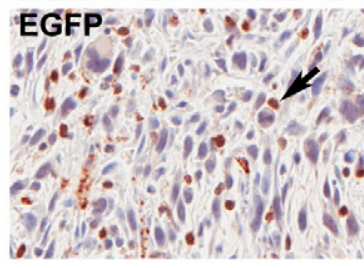

B
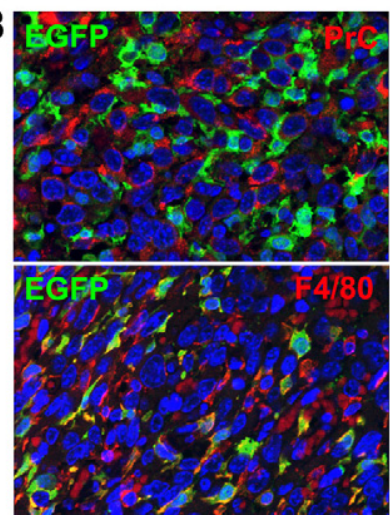

B-gal

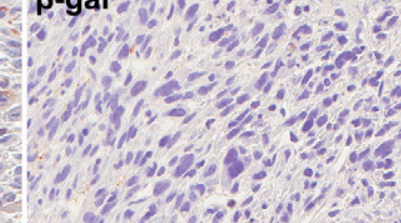

EGFP
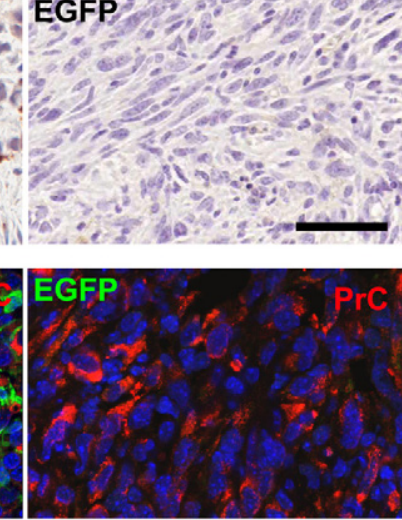

EGFP

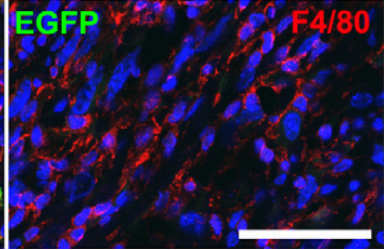

Figure 7. Detection of bone marrow-derived cells in soft tissue sarcomas. A: Expression of $\beta$-galactosidase ( $\beta$-gal, arrow) and EGFP (arrow) in sarcomas initiated by a single SC AdCMVCre injection into lethally irradiated p53 ${ }^{\text {loxP/loxP }} R b^{\text {loxp/loxp }}$ mice transplanted with bone marrow cells from Rosa26LacZ (upper left panel) and B5/EGFP reporter mice (lower left panel) but not in those with Rosa26Stop ${ }^{\text {loxP }}$ LacZ (upper right panel) or a $Z / E G$ (lower right panel) bone marrow cells. ABC Elite method with hematoxylin counterstaining. B: Expression of EGFP, procollagen type I $(\mathrm{PrC})$, and $\mathrm{F} 4 / 80$ markers in sarcomas of $p 53^{\text {loxP/loxP }} R b^{\text {LoxP/loxP }}$ irradiation chimeras reconstituted with bone marrow cells from a $B 5 / E G F P$ (left) and $Z / E G$ reporter mice (right). Note coexpression (yellow color) of EGFP and $\mathrm{F} 4 / 80$ in sarcoma of mouse reconstituted with $B 5 / E G F P$ bone marrow. Double immunofluorescence with DAPI counterstaining. Calibration bar: $50 \mu \mathrm{m}$ (A and B).

mice, favor a view that UPS/MFH originate from fibroblastic or mesenchymal precursor/stem cells. ${ }^{2,54-57}$ These studies have also demonstrated that UPS/MFH frequently contain a large number of nonneoplastic infiltrating macrophages. ${ }^{57-60}$ Consistent with those reports we observed that cells expressing macrophage markers F4/80 and/or Iba1 do not have neoplastic morphology and lack Cre-loxP-mediated recombination.

Some UPS may represent other STS that exhibit high degree of phenotypical plasticity during tumor progression. ${ }^{61-65}$ However, findings of $\mathrm{MFH}$-specific genomic alterations $^{66-68}$ and gene expression profiles ${ }^{69-71}$ indicate that diagnosis of UPS/MFH corresponds to a distinct nosological entity and may reflect development of these neoplasms from MSC.

Recent progress in isolation of MSC and their potential use in therapeutic approaches ${ }^{72-73}$ have renewed interest in assessment of transformation potential of these cells. By using human bone marrow MSC Matushansky et $\mathrm{al}^{5}$ demonstrated that the expression pattern of these cells correlates with that of UPS/MFH. Furthermore, they
A
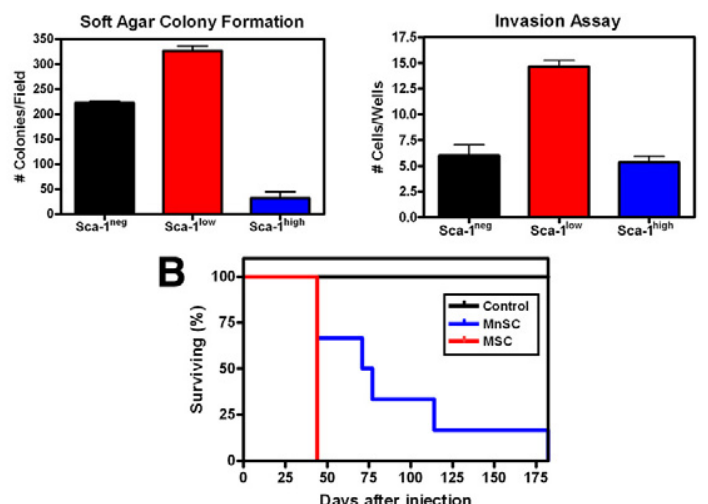

C

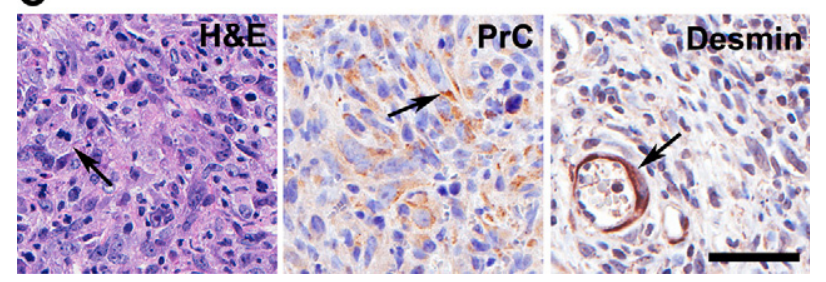

Figure 8. Neoplastic potential of dermal mesenchymal stem cells (MSC) after conditional inactivation of $\mathrm{p} 53$ and $\mathrm{Rb}$. A: Compared with Sca- ${ }^{\text {neg }}$ and Sca- $1^{\text {high }}$ subpopulations, the Sca- $1^{\text {low }}$ MSC cells have significantly higher propensity for forming colonies in soft agar (left panel, mean $\pm \mathrm{SD}, n=3$, $P<0.0001$ ) and invasion in Matrigel chamber (right panel, mean $\pm \mathrm{SD}, n=$ 3. Sca- $1^{\text {low }}$ versus Sca- $1^{\text {neg }}, P=0.0002$; Sca- $1^{\text {low }}$ versus Sca- $1^{\text {high }}, P<$ 0.0001). B: Accelerated formation of tumors after SC transplantation of MSC (median survival 44 days, $n=3$ ) compared with mesenchymal non-stem cells (MnSC, median survival 74 days, $n=6 ; P=0.0376$ ). C: Undifferentiated high-grade pleomorphic sarcoma with mitotic figures (H\&E, arrow) and expression of procollagen type I ( $\mathrm{PrC}$, arrow) formed after MSC implantation. Desmin is detected only in smooth muscle cells of blood vessels (arrow). Left panel, Hematoxylin and eosin, lower, middle, and right panels, $\mathrm{ABC}$ Elite method with hematoxylin counterstaining. Calibration bar $=50 \mu \mathrm{m}$.

demonstrated that MSC immortalized with SV-40 large T antigen recapitulated UPS/MFH morphology after subcutaneous transplantation into nude mice. Consistently, formation of UPS was reported after transplantation of bone marrow-derived mouse MSC treated with 2-methylcholanthrene. ${ }^{7}$ Intriguingly, it has been reported that according to cell lineage tracing experiments in irradiation chimeras, spontaneous fibrosarcomas arise from bone marrow-derived cells in the mouse. ${ }^{74}$

To evaluate a possibility of bone marrow origin of STS in our model, we have performed irradiation chimera experiments in which donor and recipient cells carried floxed copies of $p 53$ and $R b$. Given 24\% reconstitution of dermal macrophage population in irradiation chimeras, $70 \%$ frequency of UPS in our model and near equal infectivity of macrophages and fibroblasts by adenovirus, one would expect that sarcomas in six to seven mice could arise from macrophages. However, none of 38 mice developed STS from bone marrow with floxed p53 and $R b$. These results provide the direct experimental evidence that UPS/MFH do not arise from macrophages and indicate that initiation of sarcomas from bone marrow-derived cells is unlikely.

To test whether STS may preferentially arise from local resident MSC after $p 53$ and $R b$ inactivation we have isolated dermal mesenchymal stem/progenitors cells 
based on their adherence to plastic and expression of Sca-1 marker (Ly-6A/E) in combination with negative selection for CD45 and CD31. Sca-1 has been shown to be an effective marker for stem cells in many different tissues, including MSC. ${ }^{75-79}$ Interestingly, in our experiments the Sca- $1^{\text {low }}$ population was enriched for multipotent cells. It was reported that Sca-1 $1^{\text {low }}$ population was more enriched for stem cells than the expected Sca- $1^{\text {high }}$ population in the mammary epithelial cells ${ }^{80}$ and low levels of positive staining for Sca-1 were detected in spermatogonial stem cells. ${ }^{81}$ Similar to these observations we also found that prolonged culturing of cells, before staining and FACS, induced expression of Sca-1 (our unpublished observations). Therefore, it is quite possible that the culture step necessary to select for plastic adherence upregulated Sca-1 expression in the PAD cells, throwing off the Sca-1 expression levels that would be expected based on the majority of studies that sort cells before any culturing. ${ }^{75,82}$

By using isolated dermal MSC enriched in the Sca- $1^{\text {low }}$ fraction we were able to demonstrate their increased transformation potential, as comported to more differentiated connective tissue cells of the dermis, after inactivation of $p 53$ and $R b$. Interestingly, transformation of dermal MSC resulted in formation of UPS, consistent with previous reports which used bone marrow MSC. ${ }^{5,7}$ At the same time, Rodriguez et al ${ }^{35}$ reported formation of fibrosarcomas with areas of adipose tissue differentiation after subcutaneous injection of MSC derived from adipose tissue of $p 21^{-1-} p 53^{-1-}$ mice into immunodeficient mice. These variations in tumor type may reflect either different differentiation potential of MSC derived from different locations or gene-dependent differentiation potential.

Recent observations indicate that $p 53$ and $R b$ tumor suppressors have important functions in stem cells. p53 has been shown to mediate the onset of senescence of endothelial progenitor cells, to negatively regulate proliferation and survival of neural stem cells, to induce differentiation of embryonic stem cells, and to control efficiency of induced pluripotent stem cell generation. ${ }^{83-85}$ $R b$ and its pathway are involved in control of stem cell cycle progression, senescence and tissue homeostasis. ${ }^{86}$ It has been reported that fibroblasts lacking $\mathrm{Rb}$ form spheres and become cancer stem cells. ${ }^{87}$ Notably, p16/Rb and ARF/p53 pathways are extensively connected and may be coordinately regulated by Bmi-1, which is required for maintenance and self-renewal of hematopoietic and neural stem and progenitor cells. ${ }^{88}$ Consistently it has been demonstrated that combined p53 and Rb deficiency results in prostate cancer arising from the prostate stem cell compartment. ${ }^{33}$ Further studies of established STS model will address the specific molecular and cellular mechanisms responsible for cooperation of p53 and Rb in control of MSC and their malignant transformation. It also remains to be addressed whether sarcomas with distinct differentiation features, such as leiomyosarcoma and angiosarcoma, originate from MSC or more committed progenitor cells which are less prone to transformation after $p 53$ and $R b$ inactivation. It is of interest that according to comparative genomic hybridization studies, UPS/MFH share similari- ties with leiomyosarcomas, ${ }^{70,89}$ consistent with frequent observations of areas of smooth muscle differentiation in UPS, including our model.

In conclusion, we have established a genetically engineered mouse model of the STS by temporally and spatially controlled $p 53$ and $R b$ inactivation in connective tissue cells of the dermis. We have also demonstrated that STS develop locally, most likely from MSC. This mouse model of STS will serve as a valuable basis for future studies of STS pathogenesis, particularly of those for sarcomas with complex genotypes. This model also provides new opportunities for exploration of targeted therapies and screening for novel therapeutic agent to treat the disease.

\section{Acknowledgments}

We thank Dr. Anton Berns (Netherlands Cancer Institute, Amsterdam, the Netherlands) for the generous gift of the p53 $3^{\text {loxP/loxP }}$ and $R b^{\text {loxP/loxP }}$ mice, Dr. Margaret Colleen McEntee (Cornell College of Veterinary Medicine) for helping with mice irradiation, James Smith III, (Biomedical Sciences Flow Cytometry Core Laboratory) for help with FACS experiments, Dr. Kyung-Chul Choi for his contributions to the initial stages of this project, David C. Corney for critical reading of the manuscript, and members of Nikitin lab for helpful comments.

\section{References}

1. Collini P, Sorensen PH, Patel S, Blay JY, Issels RD, Maki RG, Eriksson M, del Muro XG: Sarcomas with spindle cell morphology. Semin Oncol 2009, 36:324-337

2. Mackall CL, Meltzer PS, Helman LJ: Focus on sarcomas. Cancer Cell 2002, 2:175-178

3. Guillou L, Aurias A: Soft tissue sarcomas with complex genomic profiles. Virchows Arch 2009, Nov 13 [Epub ahead of press]

4. Weiss SW, Goldblum JR: Enzinger \& Weiss's Soft Tissue Tumors Edited by Weiss SW, Goldblum JR. Philadelphia, Mosby, Elsevier 2008, pp1-1258

5. Matushansky I, Hernando E, Socci ND, Mills JE, Matos TA, Edgar MA Singer S, Maki RG, Cordon-Cardo C: Derivation of sarcomas from mesenchymal stem cells via inactivation of the Wnt pathway. J Clin Invest 2007, 117:3248-3257

6. Tasso R, Augello A, Carida M, Postiglione F, Tibiletti MG, Bernasconi B, Astigiano S, Fais F, Truini M, Cancedda R, Pennesi G: Development of sarcomas in mice implanted with mesenchymal stem cells seeded onto bioscaffolds. Carcinogenesis 2009, 30:150-157

7. Li Q, Hisha H, Takaki T, Adachi Y, Li M, Song C, Feng W, Okazaki S, Mizokami T, Kato J, Inaba M, Hosaka N, Maki M, Ikehara S: Transformation potential of bone marrow stromal cells into undifferentiated high-grade pleomorphic sarcoma. J Cancer Res Clin Oncol 2010, 136:829-838

8. Tolar J, Nauta AJ, Osborn MJ, Panoskaltsis Mortari A, McElmurry RT, Bell S, Xia L, Zhou N, Riddle M, Schroeder TM, Westendorf JJ, Mclvor RS, Hogendoorn PC, Szuhai K, Oseth L, Hirsch B, Yant SR, Kay MA, Peister A, Prockop DJ, Fibbe WE, Blazar BR: Sarcoma derived from cultured mesenchymal stem cells. Stem Cells 2007, 25:371-379

9. Li H, Fan X, Kovi RC, Jo Y, Moquin B, Konz R, Stoicov C, Kurt-Jones E, Grossman SR, Lyle S, Rogers AB, Montrose M, Houghton J: Spontaneous expression of embryonic factors and p53 point mutations in aged mesenchymal stem cells: a model of age-related tumorigenesis in mice. Cancer Res 2007, 67:10889-10898

10. Stratton MR, Moss S, Warren W, Patterson H, Clark J, Fisher C, Fletcher CD, Ball A, Thomas M, Gusterson BA, Cooper CS: Mutation 
of the p53 gene in human soft tissue sarcomas: association with abnormalities of the RB1 gene. Oncogene 1990, 5:1297-1301

11. Walkley CR, Qudsi R, Sankaran VG, Perry JA, Gostissa M, Roth SI, Rodda SJ, Snay E, Dunning P, Fahey FH, Alt FW, McMahon AP, Orkin SH: Conditional mouse osteosarcoma, dependent on p53 loss and potentiated by loss of Rb, mimics the human disease. Genes Dev 2008, 22:1662-1676

12. Berman SD, Calo E, Landman AS, Danielian PS, Miller ES, West JC, Fonhoue BD, Caron A, Bronson R, Bouxsein ML, Mukherjee S, Lees $\mathrm{JA}$ : Metastatic osteosarcoma induced by inactivation of $\mathrm{Rb}$ and $\mathrm{p} 53$ in the osteoblast lineage. Proc Natl Acad Sci USA 2008, 105 $11851-11856$

13. Lin PP, Pandey MK, Jin F, Raymond AK, Akiyama H, Lozano G: Targeted mutation of p53 and Rb in mesenchymal cells of the limb bud produces sarcomas in mice. Carcinogenesis 2009, 30:1789-1795

14. Kirsch DG, Dinulescu DM, Miller JB, Grimm J, Santiago PM, Young NP, Nielsen GP, Quade BJ, Chaber CJ, Schultz CP, Takeuchi O, Bronson RT, Crowley D, Korsmeyer SJ, Yoon SS, Hornicek FJ, Weissleder R, Jacks T: A spatially and temporally restricted mouse model of soft tissue sarcoma. Nat Med 2007, 13:992-997

15. Jonkers J, Meuwissen R, van der Gulden $\mathrm{H}$, Peterse $\mathrm{H}$, van der Valk M, Berns A: Synergistic tumor suppressor activity of BRCA2 and p53 in a conditional mouse model for breast cancer. Nat Genet 2001 29:418-425

16. Marino S, Vooijs M, van Der Gulden H, Jonkers J, Berns A: Induction of medulloblastomas in p53-null mutant mice by somatic inactivation of $\mathrm{Rb}$ in the external granular layer cells of the cerebellum. Genes Dev 2000, 14:994-1004

17. Novak A, Guo C, Yang W, Nagy A, Lobe CG: Z/EG, a double reporter mouse line that expresses enhanced green fluorescent protein upon Cre-mediated excision. Genesis 2000, 28:147-155

18. Chai $Y$, Jiang $X$, Ito $Y$, Bringas $P$ Jr, Han J, Rowitch DH, Soriano $P$, McMahon AP, Sucov HM: Fate of the mammalian cranial neural crest during tooth and mandibular morphogenesis. Development 2000 127:1671-1679

19. Jiang $X$, Rowitch DH, Soriano P, McMahon AP, Sucov HM: Fate of the mammalian cardiac neural crest. Development 2000, 127:1607-1616

20. Hadjantonakis AK, Gertsenstein M, Ikawa M, Okabe M, Nagy A: Generating green fluorescent mice by germline transmission of green fluorescent ES cells. Mech Dev 1998, 76:79-90

21. Soriano P: Generalized lacZ expression with the ROSA26 Cre reporter strain. Nat Genet 1999, 21:70-71

22. Flesken-Nikitin A, Choi KC, Eng JP, Shmidt EN, Nikitin AY: Induction of carcinogenesis by concurrent inactivation of p53 and Rb1 in the mouse ovarian surface epithelium. Cancer Res 2003, 63:3459-3463

23. Anderson RD, Haskell RE, Xia H, Roessler BJ, Davidson BL: A simple method for the rapid generation of recombinant adenovirus vectors. Gene Ther 2000, 7:1034-1038

24. Choi J, Burns AA, Williams RM, Zhou Z, Flesken-Nikitin A, Zipfel WR, Wiesner U, Nikitin AY: Core-shell silica nanoparticles as fluorescent labels for nanomedicine. J Biomed Opt 2007, 12:064007

25. Cui YZ, Hisha H, Yang GX, Fan TX, Jin T, Li Q, Lian Z, Ikehara S: Optimal protocol for total body irradiation for allogeneic bone marrow transplantation in mice. Bone Marrow Transplant 2002, 30:843-849

26. McDonald TP, Lange RD, Congdon CC, Toya RE: Effect of hypoxia, irradiation, and bone marrow transplantation on erythropoietin levels in mice. Radiat Res 1970, 42:151-163

27. Mohr U: International Classification of Rodent Tumours. The Mouse. Edited by Mohr U. Berlin, Heidelberg, Springer 2001, pp1-474

28. Zhou Z, Flesken-Nikitin A, Corney DC, Wang W, Goodrich DW, RoyBurman P, Nikitin AY: Synergy of p53 and Rb deficiency in a conditional mouse model for metastatic prostate cancer. Cancer Res 2006 66:7889-7898

29. Matoso A, Zhou Z, Hayama R, Flesken-Nikitin A, Nikitin AY: Cell lineage-specific interactions between Men1 and $\mathrm{Rb}$ in neuroendocrine neoplasia. Carcinogenesis 2008, 29:620-628

30. Wilson L, Fathke C, Isik F: Tissue dispersion and flow cytometry for the cellular analysis of wound healing. Biotechniques 2002, 32:548-551

31. Corney DC, Hwang Cl, Matoso A, Vogt M, Flesken-Nikitin A, Godwin AK, Kamat AA, Sood AK, Ellenson LH, Hermeking H, Nikitin AY: Frequent downregulation of miR-34 family in human ovarian cancers. Clin Cancer Res 2010, 16:1119-1128

32. Corney DC, Flesken-Nikitin A, Godwin AK, Wang W, Nikitin AY: Mi-
croRNA-34b and MicroRNA-34c are targets of p53 and cooperate in control of cell proliferation and adhesion-independent growth. Cancer Res 2007, 67:8433-8438

33. Zhou Z, Flesken-Nikitin A, Nikitin AY: Prostate cancer associated with p53 and Rb deficiency arises from the stem/progenitor cell-enriched proximal region of prostatic ducts. Cancer Res 2007, 67:5683-5690

34. Oda Y, Tateishi N, Matono H, Matsuura S, Yamamaoto H, Tamiya S, Yokoyama R, Matsuda S, Iwamoto Y, Tsuneyoshi M: Chemokine receptor CXCR4 expression is correlated with VEGF expression and poor survival in soft-tissue sarcoma. Int J Cancer 2009, 124:1852-1859

35. Rodriguez R, Rubio R, Masip M, Catalina P, Nieto A, de la Cueva T, Arriero M, San Martin N, de la Cueva E, Balomenos D, Menendez P, Garcia-Castro J: Loss of p53 induces tumorigenesis in p21-deficient mesenchymal stem cells. Neoplasia 2009, 11:397-407

36. Jemal A, Siegel R, Ward E, Hao Y, Xu J, Thun MJ: Cancer statistics, 2009. CA Cancer J Clin 2009, 59:225-249

37. Muller A, Homey B, Soto H, Ge N, Catron D, Buchanan ME, McClanahan T, Murphy E, Yuan W, Wagner SN, Barrera JL, Mohar A, Verastegui E, Zlotnik A: Involvement of chemokine receptors in breast cancer metastasis. Nature 2001, 410:50-56

38. Taichman RS, Cooper C, Keller ET, Pienta KJ, Taichman NS, McCauley LK: Use of the stromal cell-derived factor-1/CXCR4 pathway in prostate cancer metastasis to bone. Cancer Res 2002, 62:1832-1837

39. Scala S, Ottaiano A, Ascierto PA, Cavalli M, Simeone E, Giuliano P, Napolitano M, Franco R, Botti G, Castello G: Expression of CXCR4 predicts poor prognosis in patients with malignant melanoma. Clin Cancer Res 2005, 11:1835-1841

40. Yasumoto K, Koizumi K, Kawashima A, Saitoh Y, Arita Y, Shinohara K, Minami T, Nakayama T, Sakurai H, Takahashi Y, Yoshie O, Saiki I: Role of the CXCL12/CXCR4 axis in peritoneal carcinomatosis of gastric cancer. Cancer Res 2006, 66:2181-2187

41. Oda Y, Yamamoto H, Tamiya S, Matsuda S, Tanaka K, Yokoyama R, Iwamoto Y, Tsuneyoshi M: CXCR4 and VEGF expression in the primary site and the metastatic site of human osteosarcoma: analysis within a group of patients, all of whom developed lung metastasis. Mod Pathol 2006, 19:738-745

42. Strahm B, Durbin AD, Sexsmith E, Malkin D: The CXCR4-SDF1alpha axis is a critical mediator of rhabdomyosarcoma metastatic signaling induced by bone marrow stroma. Clin Exp Metastasis 2008, 25:1-10

43. Mehta SA, Christopherson KW, Bhat-Nakshatri P, Goulet RJ, Jr. Broxmeyer HE, Kopelovich L, Nakshatri H: Negative regulation of chemokine receptor CXCR4 by tumor suppressor p53 in breast cancer cells: implications of p53 mutation or isoform expression on breast cancer cell invasion. Oncogene 2007, 26:3329-3337

44. Engellau J, Anderson H, Rydholm A, Bauer HC, Hall KS, Gustafson P, Akerman M, Meis-Kindblom J, Alvegard TA, Nilbert M: Time dependence of prognostic factors for patients with soft tissue sarcoma: a Scandinavian Sarcoma Group Study of 338 malignant fibrous histiocytomas. Cancer 2004, 100:2233-2239

45. Kauffman SL, Stout AP: Histiocytic tumors (fibrous xanthoma and histiocytoma) in children. Cancer 1961, 14:469-482

46. Ozzello L, Stout AP, Murray MR: Cultural characteristics of malignant histiocytomas and fibrous xanthomas. Cancer 1963, 16:331-344

47. O'Brien JE, Stout AP: Malignant fibrous xanthomas. Cancer 1964, 17:1445-1455

48. Yumoto T, Morimoto K: Experimental approach to fibrous histiocytoma. Acta Pathol Jpn 1980, 30:767-778

49. Shirasuna K, Sugiyama M, Miyazaki T: Establishment and characterization of neoplastic cells from a malignant fibrous histiocytoma: a possible stem cell line. Cancer 1985, 55:2521-2532

50. Strauchen JA, Dimitriu-Bona A: Malignant fibrous histiocytoma: expression of monocyte/macrophage differentiation antigens detected with monoclonal antibodies. Am J Pathol 1986, 124:303-309

51. Hagari $Y$, Yumoto $T$ : Experimental tumors of myxoid malignant fibrous histiocytoma and hyaluronic acid production. Acta Pathol Jpn 1987 37:975-988

52. Yamate J, Tajima M, Togo M, Shibuya K, Ihara M, Kudow S: Heterogeneity of cloned cell lines established from a transplantable rat malignant fibrous histiocytoma. Jpn J Cancer Res 1991, 82:298-307

53. Binder SW, Said JW, Shintaku IP, Pinkus GS: A histiocyte-specific marker in the diagnosis of malignant fibrous histiocytoma: use of monoclonal antibody KP-1 (CD68) Am J Clin Pathol 1992, 97: 759-763 
54. Fu YS, Gabbiani G, Kaye GI, Lattes R: Malignant soft tissue tumors of probable histiocytic origin (malignant fibrous histiocytomas): general considerations and electron microscopic and tissue culture studies. Cancer 1975, 35:176-198

55. Hoffman MA, Dickersin GR: Malignant fibrous histiocytoma: an ultrastructural study of eleven cases. Hum Pathol 1983, 14:913-922

56. Nikitin AY, Rajewsky MF, Pozharisski KM: Development of malignant fibrous histiocytoma induced by 7,12-dimethylbenz[a]anthracene in the rat: characterization of early atypical cells. Virchows Arch B Cell Pathol Incl Mol Pathol 1993, 64:151-159

57. Takeya M, Yamashiro S, Yoshimura T, Takahashi K: Immunophenotypic and immunoelectron microscopic characterization of major constituent cells in malignant fibrous histiocytoma using human cell lines and their transplanted tumors in immunodeficient mice. Lab Invest 1995, 72:679-688

58. Roessner A, Vassallo J, Vollmer E, Zwadlo G, Sorg C, Grundmann E: Biological characterization of human bone tumors. X. The proliferation behavior of macrophages as compared to fibroblastic cells in malignant fibrous histiocytoma and giant cell tumor of bone. J Cancer Res Clin Oncol 1987, 113:559-562

59. Kato T, Takeya M, Takagi K, Takahashi K: Chemically induced transplantable malignant fibrous histiocytoma of the rat. Analyses with immunohistochemistry, immunoelectron microscopy and $[3 \mathrm{H}]$ thymidine autoradiography. Lab Invest 1990, 62:635-645

60. Takeya M, Yoshimura T, Leonard EJ, Kato T, Okabe H, Takahashi K: Production of monocyte chemoattractant protein-1 by malignant fibrous histiocytoma: relation to the origin of histiocyte-like cells. Exp Mol Pathol 1991, 54:61-71

61. Brooks JJ: The significance of double phenotypic patterns and markers in human sarcomas. A new model of mesenchymal differentiation Am J Pathol 1986, 125:113-123

62. Dehner LP: Regressing atypical histiocytosis: the controversy continues. Arch Dermatol 1988, 124:319-321

63. Katenkamp D: Cellular heterogeneity. Explanation for changing of tumor phenotype and biologic behavior in soft tissue sarcomas. Pathol Res Pract 1988, 183:698-705

64. Fletcher CD: Pleomorphic malignant fibrous histiocytoma: fact or fiction? A critical reappraisal based on 159 tumors diagnosed as pleomorphic sarcoma. Am J Surg Pathol 1992, 16:213-228

65. Hollowood K, Fletcher CD: Malignant fibrous histiocytoma: morphologic pattern or pathologic entity? Semin Diagn Pathol 1995, 12:210-220

66. Meltzer PS, Jankowski SA, Dal Cin P, Sandberg AA, Paz IB, Coccia $M A$ : Identification and cloning of a novel amplified DNA sequence in human malignant fibrous histiocytoma derived from a region of chromosome 12 frequently rearranged in soft tissue tumors. Cell Growth Differ 1991, 2:495-501

67. Mairal A, Terrier P, Chibon F, Sastre X, Lecesne A, Aurias A: Loss of chromosome 13 is the most frequent genomic imbalance in malignant fibrous histiocytomas. A comparative genomic hybridization analysis of a series of 30 cases. Cancer Genet Cytogenet 1999, 111:134-138

68. Mandahl N, Heim S, Willen H, Rydholm A, Eneroth M, Nilbert M, Kreicbergs A, Mitelman F: Characteristic karyotypic anomalies identify subtypes of malignant fibrous histiocytoma. Genes Chromosomes Cancer 1989, 1:9-14

69. Nielsen TO, West RB, Linn SC, Alter O, Knowling MA, O'Connell JX, Zhu S, Fero M, Sherlock G, Pollack JR, Brown PO, Botstein D, van de Rijn M: Molecular characterisation of soft tissue tumours: a gene expression study. Lancet 2002, 359:1301-1307

70. Segal NH, Pavlidis P, Antonescu CR, Maki RG, Noble WS, DeSantis D, Woodruff JM, Lewis JJ, Brennan MF, Houghton AN, Cordon-Cardo C: Classification and subtype prediction of adult soft tissue sarcoma by functional genomics. Am J Pathol 2003, 163:691-700
71. Gazziola C, Cordani N, Wasserman B, Carta S, Colombatti A, Perris R: Malignant fibrous histiocytoma: a proposed cellular origin and identification of its characterizing gene transcripts. Int J Oncol 2003, 23:343-351

72. Toma JG, Akhavan M, Fernandes KJ, Barnabe-Heider F, Sadikot A Kaplan DR, Miller FD: Isolation of multipotent adult stem cells from the dermis of mammalian skin. Nat Cell Biol 2001, 3:778-784

73. Mata A, Boehm C, Fleischman AJ, Muschler G, Roy S: Growth of connective tissue progenitor cells on microtextured polydimethylsiloxane surfaces. J Biomed Mater Res 2002, 62:499-506

74. Li WT, Leu YC: Effects of low level red-light irradiation on the proliferation of mesenchymal stem cells derived from rat bone marrow. Conf Proc IEEE Eng Med Biol Soc 2007, 2007:5830-5833

75. Xin L, Lawson DA, Witte ON: The Sca-1 cell surface marker enriches for a prostate-regenerating cell subpopulation that can initiate prostate tumorigenesis. Proc Natl Acad Sci USA 2005, 102:6942-6947

76. Meirelles Lda S, Nardi NB: Murine marrow-derived mesenchymal stem cell: isolation, in vitro expansion, and characterization. $\mathrm{Br} J$ Haematol 2003, 123:702-711

77. Oh H, Chi X, Bradfute SB, Mishina Y, Pocius J, Michael LH, Behringer RR, Schwartz RJ, Entman ML, Schneider MD: Cardiac muscle plasticity in adult and embryo by heart-derived progenitor cells. Ann NY Acad Sci 2004, 1015:182-189

78. Welm BE, Tepera SB, Venezia T, Graubert TA, Rosen JM, Goodell MA: Sca-1(pos) cells in the mouse mammary gland represent an enriched progenitor cell population. Dev Biol 2002, 245:42-56

79. Sun S, Guo Z, Xiao X, Liu B, Liu X, Tang PH, Mao N: Isolation of mouse marrow mesenchymal progenitors by a novel and reliable method. Stem Cells 2003, 21:527-535

80. Stingl J, Eirew P, Ricketson I, Shackleton M, Vaillant F, Choi D, Li HI, Eaves CJ: Purification and unique properties of mammary epithelial stem cells. Nature 2006, 439:993-997

81. Guan K, Nayernia K, Maier LS, Wagner S, Dressel R, Lee JH, Nolte J, Wolf F, Li M, Engel W, Hasenfuss G: Pluripotency of spermatogonial stem cells from adult mouse testis. Nature 2006, 440:1199-1203

82. Kim CF, Jackson EL, Woolfenden AE, Lawrence S, Babar I, Vogel S, Crowley D, Bronson RT, Jacks T: Identification of bronchioalveolar stem cells in normal lung and lung cancer. Cell 2005, 121:823-835

83. Stingl J, Caldas C: Molecular heterogeneity of breast carcinomas and the cancer stem cell hypothesis. Nat Rev Cancer 2007, 7:791-799

84. Zhao Y, Yin X, Qin H, Zhu F, Liu H, Yang W, Zhang Q, Xiang C, Hou P, Song Z, Liu Y, Yong J, Zhang P, Cai J, Liu M, Li H, Li Y, Qu X, Cui K, Zhang W, Xiang T, Wu Y, Zhao Y, Liu C, Yu C, Yuan K, Lou J, Ding $\mathrm{M}$, Deng $\mathrm{H}$ : Two supporting factors greatly improve the efficiency of human iPSC generation. Cell Stem Cell 2008, 3:475-479

85. Feng $\mathrm{B}, \mathrm{Ng} \mathrm{JH}$, Heng JC, $\mathrm{Ng} \mathrm{HH}$ : Molecules that promote or enhance reprogramming of somatic cells to induced pluripotent stem cells. Cell Stem Cell 2009, 4:301-312

86. Galderisi U, Cipollaro M, Giordano A: The retinoblastoma gene is involved in multiple aspects of stem cell biology. Oncogene 2006, 25:5250-5256

87. Liu Y, Clem B, Zuba-Surma EK, El-Naggar S, Telang S, Jenson AB, Wang Y, Shao H, Ratajczak MZ, Chesney J, Dean DC: Mouse fibroblasts lacking RB1 function form spheres and undergo reprogramming to a cancer stem cell phenotype. Cell Stem Cell 2009, 4:336-347

88. Valk-Lingbeek ME, Bruggeman SW, van Lohuizen M: Stem cells and cancer; the polycomb connection. Cell 2004, 118:409-418

89. Derre J, Lagace R, Nicolas A, Mairal A, Chibon F, Coindre JM, Terrier P, Sastre X, Aurias A: Leiomyosarcomas and most malignant fibrous histiocytomas share very similar comparative genomic hybridization imbalances: an analysis of a series of 27 leiomyosarcomas. Lab Invest 2001, 81:211-215 